\title{
Industrial Animal Farming and Zoonotic Risk: COVID-19 as a Gateway to Sustainable Change? A Scoping Study
}

\author{
Wolfgang Brozek ${ }^{1}(\mathbb{D})$ and Christof Falkenberg ${ }^{2, *}$ (D) \\ 1 Agency for Preventive and Social Medicine, 6900 Bregenz, Austria; Wolfgang.brozek@aks.or.at \\ 2 Institute for Marketing and Innovation, University of Natural Resources and Life Sciences, \\ 1180 Vienna, Austria \\ * Correspondence: Christof.falkenberg@boku.ac.at
}

Citation: Brozek, W.; Falkenberg, C. Industrial Animal Farming and

Zoonotic risk: COVID-19 as a

Gateway to Sustainable Change? A Scoping Study. Sustainability 2021, 13, 9251. https://doi.org/10.3390/ su13169251

Academic Editor: Tina

Soliman Hunter

Received: 9 July 2021

Accepted: 14 August 2021

Published: 18 August 2021

Publisher's Note: MDPI stays neutral with regard to jurisdictional claims in published maps and institutional affiliations.

Copyright: (c) 2021 by the authors. Licensee MDPI, Basel, Switzerland. This article is an open access article distributed under the terms and conditions of the Creative Commons Attribution (CC BY) license (https:// creativecommons.org/licenses/by/ $4.0 /)$.

\begin{abstract}
The threat of zoonoses (i.e., human infectious diseases transmitted from animals) because of industrial animal farming may be receiving less attention in society due to the putative wildlife origin of COVID-19. To identify societal responses to COVID-19 that do address or affect the risk of future zoonoses associated with industrial animal farming, the literature was screened for measures, actions, proposals and attitudes following the guidelines of a scoping review. Forty-one articles with relevant information published between 1 January 2020 and 30 April 2021 were identified directly or indirectly via bibliographies from 138 records retrieved via Google Scholar. Analysis of relevant content revealed ten fields of policy action amongst which biosecurity and change in dietary habits were the dominant topics. Further searches for relevant records within each field of policy action retrieved another eight articles. Identified responses were furthermore classified and evaluated according to groups of societal actors, implying different modes of regulation and governance. Based on the results, a suggested policy strategy is presented for moving away from food production in factory farms and supporting sustainable farming, involving the introduction of a tax on the demand side and subsidies for the development and production of alternative meat.
\end{abstract}

Keywords: COVID-19; industrial livestock farming; factory farming; zoonoses; zoonotic risk; societal responses; zoonotic tax; alternative meat

\section{Introduction}

The ravages of the COVID-19 pandemic that, besides its impact on human health, has engendered pervasive social and economic corollaries, has raised public awareness of animals as a source of human pathogens. Since the first cases of severe pneumonia due to the SARS-CoV-2 coronavirus were recorded in December 2019 in Wuhan in the Chinese province of Hubei [1,2], it has become a likely scenario that the virus originated in bats as primary hosts, and, via further spread to intermediary hosts, such as pangolins, jumped the species barrier to humans [3,4]. This transmission is deemed to have happened at the Huanan Seafood Wholesale Market in Wuhan through the close contact of customers with live animals or meat [3-5].

According to the World Health Organization, "any disease or infection that is naturally transmissible from vertebrate animals to humans" is defined a zoonosis or zoonotic disease [6]. More than half of all known human pathogens have been reported to be zoonoses [7], COVID-19 being thus but one out of a plethora of zoonotic diseases that have been afflicting mankind. Among infectious diseases that have emerged since 1940-2004, the proportion of zoonoses amounts to roughly 60\% [8], and among emerging and re-emerging infectious diseases that have arisen or reappeared within the last decades since the 1970s [9], the proportion increases even further up to 73\% [7], with a disproportionate representation of viruses [7]. Importantly, efficient transmissibility among humans is a necessary precondition for a zoonotic pathogen, such as SARS-CoV-2, to precipitate an epi- or even pandemic [10]. Besides COVID-19, notorious examples of zoonoses include AIDS/HIV, 
cholera, Ebola, influenza, Lyme disease, malaria, measles, Middle East respiratory syndrome (MERS), plague, Rift Valley fever, smallpox, tuberculosis, variant Creutzfeldt-Jakob disease, West Nile fever and Zika virus disease [11-14]. Many of these have been major causes of death throughout the recent history of humanity [14].

The COVID-19 crisis is already the third pandemic of the 21st century due to the fact of a zoonotic pathogen. The origins of the global SARS epidemic in 2002 and 2003, caused by the SARS-CoV coronavirus, were traced to wildlife trade in South China [15], akin to the onset of the COVID-19 outbreak. By contrast, the influenza pandemic of 2009 and 2010 due to the H1N1 influenza A virus, also referred to as "swine flu", took its course from industrial pig farms in Mexico [16,17]. Even though $72 \%$ of infectious zoonotic diseases having emerged between 1940 and 2004 originated from wildlife [8], intensive livestock farming is held as a major driver of the emergence of infectious diseases [18-20]. Indeed, the past quarter century has seen further zoonotic outbreaks attributed to industrial farming that have, however, not become pandemic owing to restricted human-to-human transmissibility of the respective pathogenic agents. These zoonotic events include repeated epidemics caused by the avian influenza virus H5N1 ("bird flu"), associated with industrial poultry farming that first appeared in Hong Kong in 1997 [20,21], and the Nipah virus encephalitis outbreak in Malaysia in 1998 and 1999 elicited by intensive pig farming [22].

Food animal production has undergone a transformation towards intensification and industrialization that in many parts of the world commenced before the middle of the last century [23]. This change has been driven by at least three major forces associated with increasing demand for meat, i.e., the rapidly growing world population; demographic changes such as proceeding urbanization; socio-economic advancement [24]. The hallmarks of intensive livestock farms, of which commonly used alternative terms include, amongst others, "factory farms", or "CAFOs" (concentrated animal feeding operations), involve the raising of animals in confinement at high densities that are fed on defined diets and deprived of foraging, moreover the application of economies of scale and automated machinery equipment as well as the use of biotechnology [23,25]. Such an environment represents an excellent breeding ground for zoonotic pathogens. The concentrated containment of large numbers of stressed wildlife not only increases the risk of disease contraction and transmission among livestock animals $[18,26]$, but these conditions likewise favour mutations and genetic recombination among diverse pathogens that are mutually transmissible between wildlife, farmed animals and humans [18,23]. For example, pig stocks play an outstanding role as "mixing vessels", facilitating genetic exchange across porcine, avian and human influenza A viruses that infect pigs, which might lead to the generation of novel zoonotic strains [27]. The spread of the pathogens outside of farms can ensue in various ways, particularly via infection of personnel in close contact with the animals (e.g., farmers, farm workers and veterinarians) and through disposal of animal waste [23,28]. Factory farms, hence, act as incubators, amplifiers and transmission ports of zoonotic pathogens [18].

The situation is aggravated because animals that render high yields as encountered on factory farms are often genetically homogeneous and, thus, more susceptible to infections and epidemics than genetically diverse livestock [29]. The resulting plentiful overuse of antibiotics on industrial farms, particularly for non-therapeutic disease prevention and growth promotion, fuels the development of multi-drug resistance in bacterial strains $[26,30,31]$. Even if these strains do not cause human infections, antibiotic resistance genes can be passed on to bacteria pathogenic to humans, which poses another major jeopardy to public health due to the fact of industrial farming [26,30,31]. Furthermore, cultivation of feed crops for livestock that requires large areas of land results in the destruction of natural habitats, deforestation and biodiversity loss [32], substantial drivers of zoonotic disease emergence [13]. In addition, the transportation of animals from factory farms to remote sites of slaughter increases the risk of transmission and spread of pathogens [33]. Nevertheless, it is sometimes claimed that mainly because of biosecurity measures and reduced contact with wildlife, factory farms are safer with respect to zoonotic risk than 
small-scale farms [34,35]; however, the drawbacks addressed above exceed any potential benefit $[34,36]$. Given that worldwide meat consumption has been rising for at least the past half century [37] and that this trend is anticipated to be sustained for the next decades [38], the significance of industrial livestock production for the emergence of future zoonotic diseases with pandemic potential will thus likely increase unless antagonized.

Encouragingly, there is evidence that responses to the COVID-19 crisis by different parts of society harbour the potential for sustainable societal change that counteract the emergence of zoonotic diseases, i.e., the causes of the crisis. In this regard, an investigation conducted in China during the early phase of the crisis in January 2020 showed that COVID19 had a strong influence on negative attitudes towards game meat as compared with organic food, particularly among the younger generations [39]. Another recent empirical study among residents of Brazil and Portugal revealed a COVID-19-stimulated increase in environmental awareness, social responsibility and sustainable consumption, and that the youngest study participants pertaining to generation $Y$, born after 1981, were the ones most sensitive to COVID-19-induced sustainable consumption patterns [40]. Moreover, certain policies as responses to COVID-19 on the part of governments and organizations could arguably trigger sustainability transitions. For example, China's ban on wildlife trade and consumption of terrestrial animals on 24 February 2020 was claimed to exert a protective effect on ecosystems and to mitigate the risk of future zoonotic events and pandemics alike [41]. Beyond that, proposals for a global ban on wildlife trade and consumption have emerged as a further response to the crisis [42,43].

Since COVID-19 presumably originated from wildlife trade on a wet market, other risk factors for zoonotic disease emergence, such as intensive livestock farming, might be receiving less attention. Therefore, the purpose of the present investigation is to clarify whether COVID-19 has stimulated societal reactions with respect to the zoonotic risk posed by factory farming and to discuss possible implications for further action. Specifically, the research questions addressed herein are which actual and proposed responses the COVID-19 crisis has prompted in society, aimed at the prevention of zoonotic risk or affecting zoonotic risk of industrial animal farming, moreover, looking at which topics the responses encompass, and which societal actors are involved. Because of the novelty of any COVID-19-related topic and the exploratory focus of the study, the approach of a scoping review was chosen to reveal recommendations and proposals as well as actual responses including policies, measures, behaviours, attitudes and beliefs in available literature since the onset of the pandemic roughly one and a half years ago (July 2021). After a description of the methodological approach, the results section will present the identified proposed and actual responses, (i) classified into thematic categories corresponding to potential fields of policy action as well as (ii) arranged according to groups of actors involved in the implementation of the responses, i.e., government, business and civil society (i.e., consumers), implying different modes of governance and diverse mechanisms by which possible changes could be effectuated. In the discussion section, findings will be critically assessed with respect to the potential of the (proposed) responses to be sustained and efficacious. Finally, a scenario will be outlined for the suggested appropriate policies in the post-COVID-19 era, and the limitations of this study will be addressed.

\section{Materials and Methods}

A review of the available literature was conducted in close adherence to the framework for scoping studies published by Arksey and O'Malley [44] and its extension by Levac et al. [45]. The steps in each of the framework's stages are described below.

\subsection{Identification of Research Questions and Relevant Articles}

In defining the research questions, a broad scope was applied, not restricted to any specific type of response (proposed and actual), stakeholder, or relation of the response to factory farming. Moreover, mapping identified responses to thematic categories and groups of societal actors corresponded to the study purpose of analysing the range of 
different responses, their relative relevance, and spheres of (potential) implementation, which was considered by the research questions and in the following framework stages.

Identification of relevant literature was carried out using the search engine Google Scholar, which covers a broad range of potentially relevant sources including, aside from peer-reviewed articles, also non-peer-reviewed pre-prints, theses and congress abstracts as well as grey literature such as technical reports and working papers. The approach to include not only peer-reviewed literature is in full line with the exploratory purpose of the present study investigating a hitherto blurred subject matter. The following combination of search terms was applied for the identification of the core literature of the present review, appearing between 1 January 2020 and 30 April 2021 without language restriction and excluding references and patents:

COVID-19 AND "future zoonoses OR zoonotic OR zoonosis" OR "zoonotic emergence OR risk" OR "pandemic risk" AND "livestock production" OR "industrial animal farming" OR "industrial food animal production" OR "intensive animal husbandry" OR "CAFO" OR "factory OR livestock farming".

By containing all common minimal variants of the concept of "factory farming" combined with future zoonotic risk, 138 hits were generated on 30 April 2021 (Figure 1). At this stage, the search strategy was narrowed, aimed at capturing the aspect of (future) zoonotic risk and prevention as a response to COVID-19. This was to avoid retrieving mostly search results of COVID-19 to be a zoonotic disease but lacking measures or recommendations for prevention.

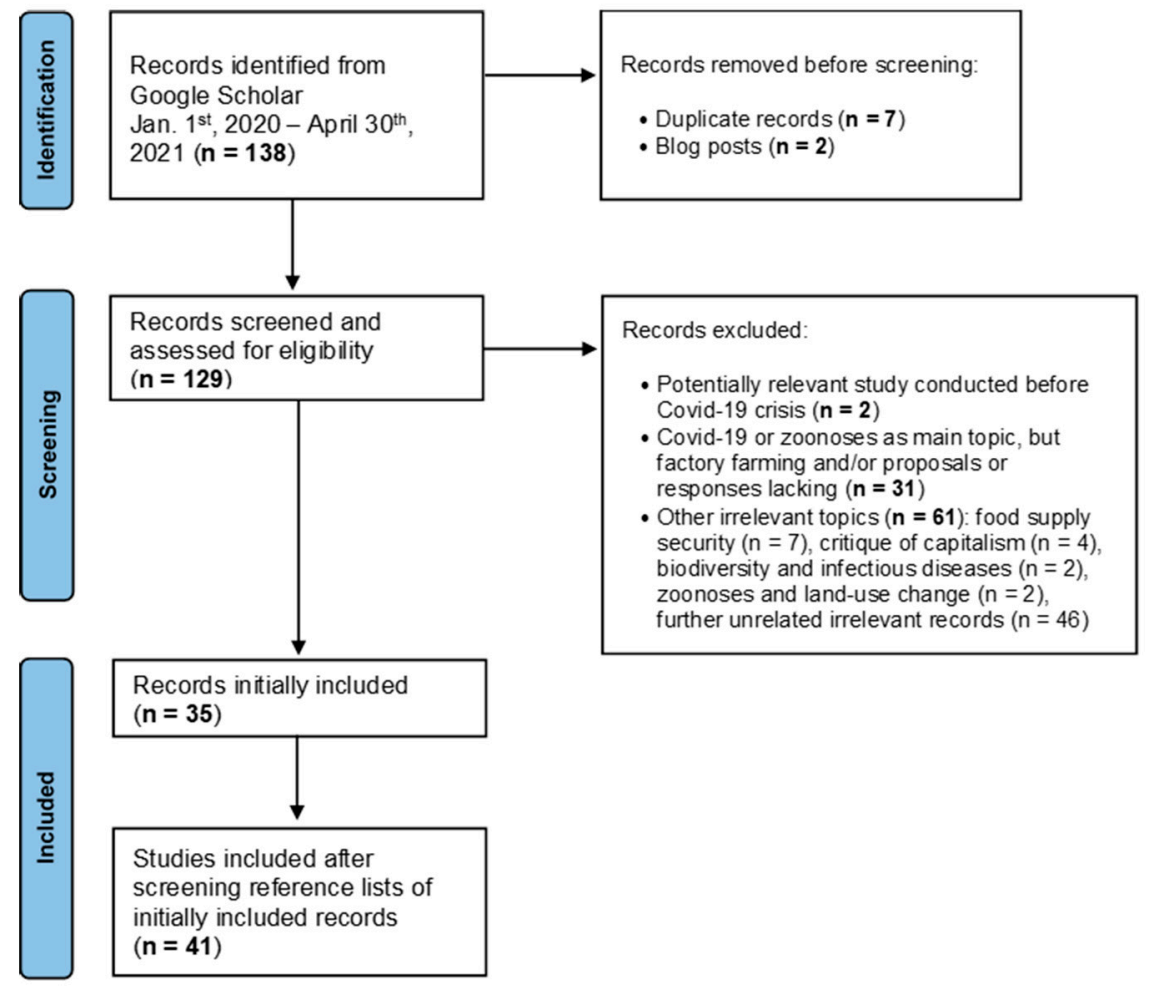

Figure 1. Flow chart of the identification of relevant core literature.

Additional searches for potentially relevant records were conducted in each of the thematic categories once these were delimitated, following the same criteria as for identification of records of the core literature. However, the search term "zoono" was used as a single truncated word rather than in combination in most of the thematic categories, in order to compensate for the narrower scope inherent to each topic (cf. Appendix A). Construction of these additional search term combinations relied upon familiarity with the core literature and must be regarded as tentative. By this, further potentially relevant records outside the core literature were located through Google Scholar queries, excluding 
references and patents, published between 1 January 2020 and May 2021 (for the exact dates, see Appendix A, where applied search term combinations and additionally identified literature are listed).

\subsection{Selection of Literature, Data Extraction and Summary of Results}

Each record retrieved by the search for the core literature was read completely to be checked for relevant content. The criteria for selection required a relevant article to contain (1) a relation between factory farming and zoonotic risk; (2) at least one recommendation, proposal, advice, suggestion, (call for) action, measure, policy or description of behaviours, attitudes or beliefs regarding or affecting this risk; (3) an explicit link in the article to the COVID-19 crisis that displayed those proposals, actions, measures, attitudes, etc., as responses to COVID-19. Blog posts that usually overtly express personal opinions and are not intended for (peer) reviewed publication were excluded from further analysis irrespective of their content; however, pre-prints, theses, grey literature, etc., were retained in accordance with the exploratory nature of this study (see above). Duplicate entries and articles with irrelevant content were removed in the next selection step (Figure 1). In each relevant article of the core literature, references were screened for further relevant studies excluding references to online newspaper articles. As typical of scoping studies, the identified literature was not rated according to quality [45].

The relevance of further literature retrieved from search terms specific for each thematic category was checked by reading only the abstracts or summaries. Records thus identified as potentially relevant according to the criteria of inclusion for core literature outlined above were only selected if they explicitly contained new information not covered by the core literature articles. The references of additional relevant literature thus identified were not screened for further relevant articles.

A flow chart of the inclusion of relevant and exclusion of irrelevant literature is depicted in Figure 1, exemplified for the identification of core literature records. In line with the research questions, each relevant content in the identified articles was furthermore assigned to thematic categories as fields of policy action. In addition, according to Steurer [46], a distinction was drawn among groups of societal actors involved in the (potential) implementation of the identified responses and policies, i.e., government, business and private sector and civil society. Governmental regulations were further classified as per type of instrument into legal, economic and informational [46], and intergovernmental and super-national governance was regarded as a further type of governmental regulation.

\section{Results}

\subsection{Identification of Relevant Literature and Thematic Categories as Fields of Action}

The process of the search for the core literature and its results are depicted in Figure 1. A query in Google Scholar yielded 138 hits from which seven duplicate entries were excluded. Two further commentaries that appeared as non-peer reviewed blog posts and another two potentially relevant studies that described results from before the onset of COVID-19 were not included. Another 92 records were ruled out due to the fact of their irrelevance, 31 of which because, even though dealing with zoonotic diseases, such as COVID-19 as a main topic, they either lacked responses, such as recommendations, policies, measures, behaviours, attitudes and beliefs, or were without reference to factory farming or both. The remainder of the excluded articles embraced topics outside the scope of the research questions. In total, 35 relevant publications were located as well as six additional articles from their bibliographies and, therefore, a total of 41 publications constituted the core literature of the present investigation. Subsequent scrutiny of the core articles for relevant content gave rise to the delimitation of 10 thematic categories as (potential) fields of policy action within which responses to COVID-19 with respect to the zoonotic risk of industrial animal farming were identified: (1) "biosecurity and animal health", concerning measures of disease prevention on farms and surveillance of emergence and spread of infectious diseases (relevant content of 20 articles of the core 
literature); (2) "dietary changes", related to dietary responses and recommendations aimed at the curbing consumption of animal products, specifically from factory farming (relevant content of 11 core literature articles), effects related to direct constraints of the crisis, e.g., change in dietary patterns due to the lockdowns were regarded as direct consequences rather than societal responses and, therefore, not considered; (3) "alternatives to animal products", i.e., options to substitute animal products, most importantly conventional meat from factory farming by novel protein sources the production of which is associated with no or lower zoonotic risk (10 relevant articles); (4) "prohibition of factory farming" as well as closure of farms as a radical approach (seven articles); (5) "taxation on animal products", i.e., levies to discourage consumption of meat and other animal-based products (five articles); (6) "economic regulation of factory farming", including investments, divestments, and taxation on the production side (five articles); (7) "support for sustainable farming", as an alternative to factory farming (five articles); (8) "One Health approach", a holistic and global scope of action of essential importance for prevention of zoonotic diseases (five articles); (9) "ban on wildlife trade", a response potentially inversely correlated with factory farming (four articles); (10) "human population degrowth", i.e., controlling human reproduction resulting in a decline in population (one article). The most important categories as assessed by the number of included records were "biosecurity and animal health", "dietary changes" and "alternatives to animal products". Additional specific searches in each of the categories for records containing new information beyond the core literature afforded another eight relevant articles, of which three were identified in "alternatives to animal products", two in "biosecurity and animal health", and one each in "dietary changes", "prohibition of factory farming" and "support for sustainable farming" (cf. Appendix A). The resulting numbers and proportions of articles with relevant content in each category are summarised in Figure 2, and a tabulation of all relevant contents is provided in Table A1 in Appendix B. In the following, identified responses are described in detail according to distinct societal actor groups that are involved in their (potential) implementation.

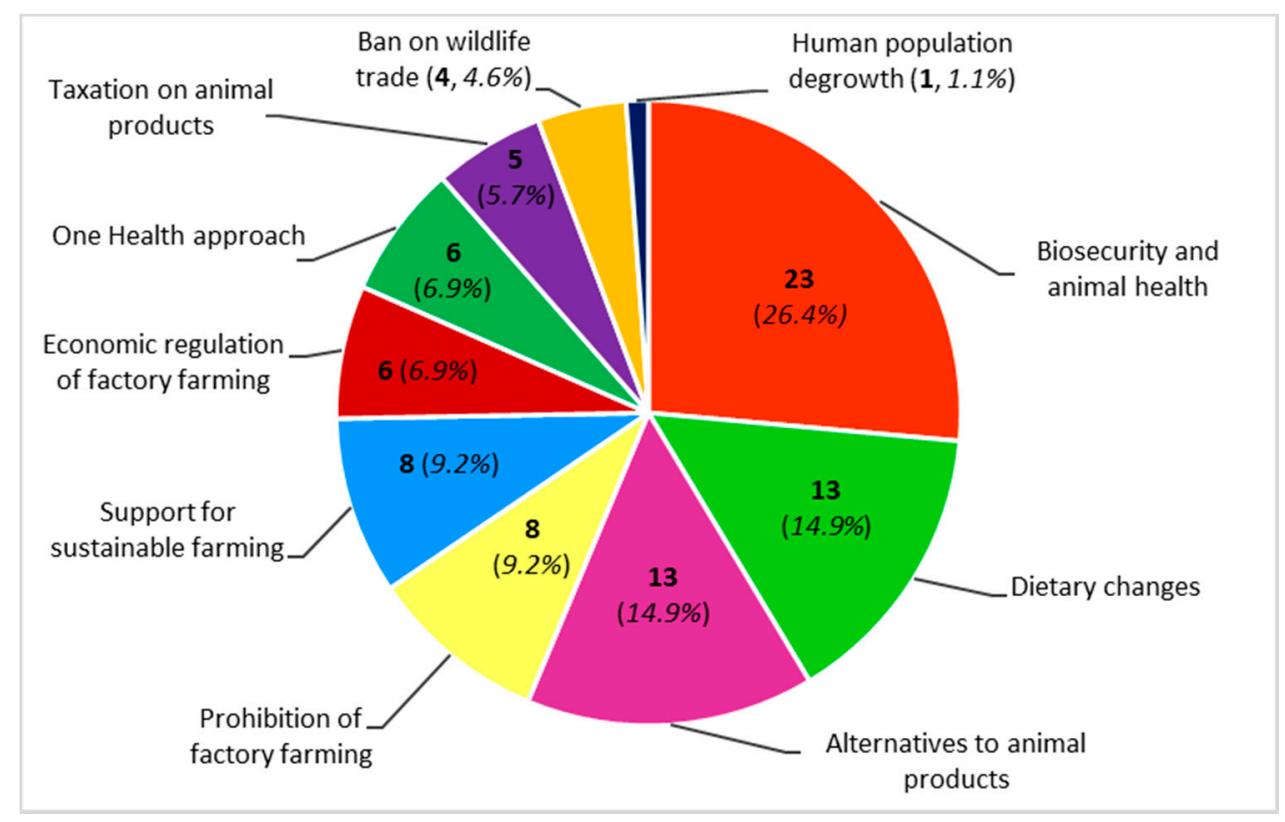

Figure 2. Pie chart showing the number (in bold) and the proportion (italic) of articles with relevant content in each thematic category. Core literature and additional relevant articles were included. 


\subsection{Governmental Responses}

\subsubsection{Legal Regulation}

The one thematic category referred to most frequently in the core literature was on farming conditions and biosecurity measures. In analysing possible solutions for preventing future zoonoses, experts from various fields have suggested a vast array of 161 options also with respect to wildlife and captive animals as well as pets [47], out of which Broom [48] pinpoints several generally applicable central issues and measures. The ones applying to biosecurity on factory farms include the wearing of protective clothing, training for farm workers, controlling access of visitors and vehicles, separation of livestock from wild animals, preventing food and water contamination, limitation of the stocking densities of animals to contribute to their welfare and enhance their immune systems, regulation of international animal transports with enforcement of detailed health checks, as well as, not treated in [47], the reduction of antibiotic overuse [48]. Along these lines and instigated by the failure of biosecurity management resulting in the COVID-19 crisis, Lindhout and Reniers [49] present a set of measures for improvement of biological safety. Besides biosafety education, hygiene measures, distancing from animals and personal protection for farm workers, the authors advocate routine disease control and preventive vaccination in farmed animals and a mechanism for rapid isolation of farms as soon as a zoonosis case is detected. Even though these measures could be implemented on a self-regulatory basis by the livestock farming business, a more efficacious and realistic means is arguably a legal framework by which to enforce such proposed policies.

Similarly, the importance of biosecurity-related measures is stressed also by other authors. These measures include restraining and controlling contact not only between humans and livestock animals [50] but also between wildlife and livestock [51]. Moreover, sanitary conditions and controls as well as quarantine measures should be established and maintained not only on farms $[49,51,52]$ but also in slaughterhouses that must be accredited [52], and wastewater from farms is to be safely disposed of [52]. In addition, general screening for microbes known to be shared by livestock and humans should be conducted [53], such as (novel strains of) SARS-CoV-2 or other viruses in mink [54,55], and infected animals should be quarantined and disposed [55]. For example, in the Netherlands, mink farms with SARS-CoV-2 infections were permanently closed, whereas those without infection cases were allowed to their businesses open on the condition of continual surveillance activities [56]. Moreover, the culling of mink in infected farms as a biosecurity measure occurred in several countries [54,56-58]. For promoting animals health, rearing on pastures would be less stressful than in crowded farming units [52], and maximum stocking densities as well as growth rates are to be legally limited, as advocated for poultry in the UK [59]. In order to enhance innate resistance to pathogens, native breeds are to be preferred over exotic ones [52], and selective breeding of farmed animals with stronger immune systems to decrease their vulnerability to diseases has also been advanced further as a proposal to reduce the use of antibiotics [60]. In this regard, it has been requested to curb non-therapeutic use of antibiotics on farms [61], in agreement with Broom [48], to prohibit antibiotic overuse [52] or even to dispense with the administration of antimicrobials facilitated by improved and healthier conditions of animal keeping [62]. For poultry farming specifically, Hedman et al. [63] point to the obligation of all countries for responsible use of antibiotics. Collectively, management of industrial agriculture to impede disease outbreaks in humans and livestock and prevention of resistance to antimicrobials should be improved, as advocated in a position statement on illegal wildlife trade [64], and the enforcement of regulations on factory farming companies to invest in measures for mitigation of infectious disease risk has been called for [65].

There have been demands to discontinue industrial farming and close all factory farms in the wake of the COVID-19 pandemic $[20,66]$, and this is what happened to mink farming in the Netherlands. SARS-CoV-2 infections in mink farms have occurred in several countries including Denmark, France, Greece, Italy, the Netherlands, Spain, Sweden and the United States [67]. As reported from Dutch farms, mutual transmissibility of SARS- 
CoV-2 facilitated the spillover of the virus from humans to mink thus causing epidemics among farmed animals where the virus genetically evolved, as well as ensuing re-infections of humans $[54,57,68]$. An immediate reaction to the infections on farms was the culling of mink in the Netherlands and Spain [54,57] as well as in Denmark where novel strains of SARS-CoV-2 associated with mink farming emerged, prompting the government to decree the killing of all (i.e., more than 17 million) farmed mink in autumn of 2020 [57,58,69]. The Netherlands took it one step further after the prohibition of mink farming had been declared as early as 2015 via a law taking full effect as of 1 January 2024 [54,56,70]. Due to the massive SARS-CoV-2 infections in Dutch mink farms, a complete ban was enacted to come into force already by the end of $2020[54,57,58]$. Banning, as far as possible, or at least monitoring or constraining mink production has been generally advocated by Xia et al. [58]. Similarly, the UK government has been requested to pursue a plan for phasing out intensive poultry farming considering its zoonotic risk and animal welfare issues, with the aim of chicken farming to become completely organic [59]. Indeed, COVID-19-induced calls for abandoning industrial animal farming are usually accompanied by demands for reforms towards sustainable and regenerative agriculture [17,59].

The prohibition of trade and consumption of meat from wildlife by the Chinese government on 24 February 2020 was a rapid response to the emergence of COVID-19. Although China has been acclaimed for this law as a milestone for averting future zoonotic pandemics [20,41], critics have pointed to possible adverse impacts if wild meat consumption and trade were banned globally. Potential risks of such a rigorous ban differ by country and region and include food insecurity, rising poverty and human rights concerns as well as conservation issues such as the encouragement of poaching and negative effects on sustainable development [19]. Furthermore, prohibition of wild meat trade and consumption could spur livestock farming as consumers seek alternatives, resulting in further habitat destruction, land-use change and biodiversity loss, additional drivers of zoonotic disease emergence $[19,64,71,72]$. In response to the pandemic, legal restrictions regarding wildlife as a food source could thus harbour unintended consequences promoting industrial farming, thereby increasing zoonotic risk.

\subsubsection{Economic Regulation}

The role of incentives to promote the shift away from industrial animal farming has been stressed by Schuck-Paim [73]. For example, imposing taxation on animal-based food as a response to COVID-19 has been suggested by several authors as a means of decreasing the consumption of animal products and the associated zoonotic risk [34,61,74,75]. By introducing such a Pigouvian or zoonotic tax [34], the government could impart an articulate message to the public discouraging the purchase of "risky" products and stimulate the adoption of more sustainable eating habits $[74,76]$. Tax revenues thus generated could be allocated to support the healthcare system or implement measures for environmental protection and natural conservation [74]. Beyond that, taxation could also apply to meat and livestock production [62,75], and revenues could be used to benefit sustainable farming and to fund public campaigns to encourage dietary change [62].

Besides taxation, Espinosa et al. have proposed to deploy incentives to stimulate early reporting of disease outbreaks by farms as well as to subsidise farms according to the zoonotic risk of their activities [34]. The rationale for the former proposal rests upon the observation that some farms might benefit from the spillover of a disease to other ones and the possibility to receive governmental compensation after the event of an epidemic [34]. In addition, the authors suggest that subsidies to farms be curtailed with the number of kept and transported animals, their genetic homogeneity and the use of nontherapeutic antibiotics but be increased with enhanced vaccination of animals [34]. Apart from regulation of industrial farming, additional funding of plant-based agriculture could be directed to promote growing food for humans rather than feed for livestock [20], and agro-ecological practices as an alternative to factory farms could be boosted by supportive policy and favourable markets [77]. Subsidies and public funding could also be directed to 
support business and research involved in the production and promotion of competitive alternatives to conventional protein sources such as plant-based products, insect-based food and cultured meat $[34,47,48,73,78-80]$. In more detail, Smith et al. [80] emphasise the need to publicly fund research conducted by US companies in the alternative meat sector, to expand existing funding and to target promising innovations such as leading to lower market prices and identification of new cell lines. In addition, regulatory mechanisms should be initiated to facilitate the market introduction of cultured meat products [79]. Finally, the longstanding proposal of negative human population growth to attain a sustainable number of people on our planet has been reinforced in the face of COVID-19 [81]. It is argued by the author that large and dense populations are prone to high pandemic risk not only due to close contact with wildlife through the need for expansion to new habitats and easy spread of pathogens in dense populations [81] but also because of factory farming to supply cheap food for the masses, under conditions favourable to the emergence of zoonotic diseases [81]. For the United States, the author suggests a sustainable reduction to 150 million inhabitants, facilitated by tax incentives to confine the maximum number of offspring to two children per family [81], whereas his other proposal to substantially restrict immigration lacks the scope of a possible global solution [81].

\subsubsection{Regulation by Informational Instruments}

To promote alternatives to animal products, such as plant-based diets, it has been suggested that public campaigns emphasising the benefits of such diets be initiated $[34,47,62]$ that could be funded by a tax on factory farming [62] and that official nutritional guidelines and recommendations with respect to the role of vegetable food be revised [34]. Public awareness should also be increased for the benefits of cultured meat products [79]. In addition, because taxes potentially become subject to habituation and have smaller effects on higher incomes, Bogueva and Marinova [74] propose to complement taxation of animal products with social marketing measures to avoid failure to achieve the desired goal of reduced meat consumption. In detail, this marketing approach comprises conveying to consumers the sustainability of environmentally friendly as well as healthy food, and the strength and ability of humans to effectuate a change for the better, i.e., to turn around global warming and prevent zoonotic diseases [74]. Further aspects to be communicated include the self-confidence for the individual that her/his actions matter and the awareness that resources are shared among humans and with other species including future generations [74]. Aside from campaigns, the introduction of an EU-wide mandatory production label informing consumers of the methods of food animal farming could contribute towards more transparency also with respect to imported products and, thus, stimulate consumers' sustainable food choices [82].

\subsubsection{Intergovernmental and Supra-National Governance}

The concept of One Health is a holistic, transdisciplinary approach that integrates the well-being of people, animals as well as the environment by means of local, national and global collaborations, and it is considered key to infectious and zoonotic disease prevention and control $[50,57,83,84]$. In a workshop report of the Intergovernmental Platform for Biodiversity and Ecosystem Services (IPBES), the coordination of this principle has been proposed to be assumed by an intergovernmental council bringing together intergovernmental organisations like the WHO (World Health Organization), OIE (Office International des Epizooties, World Organisation for Animal Health), FAO (Food and Agriculture Organization) and UNEP (United Nations Environment Programme) [75]. This council could oversee, for example, the identification of and alerts to changes that indicate pandemic risk and inform intervention and control measures [75]. Going beyond existing but poorly developed international One Health cooperation involving, for example, the WHO, OIE and FAO, it has been advocated that the One Health principle be institutionalised by national governments [75]. Importantly, an explicit scope within the One Health concept also for livestock animals was claimed by Peters [57], who moreover argues for the advancement 
of One Health to become a legal principle and for the establishment of a global animal law to rule out the possibility of permissive local regulations.

As addressed above, measures enforced by legal regulations that ensure biosecurity by monitoring disease outbreaks on farms are essential tools to mitigate zoonotic risk. On a global level, monitoring carried out with tools, such as the Global Early Warning System for Major Animal Diseases including Zoonoses (GLEWS+), a joint risk assessment, and a tracking system of zoonotic diseases operated jointly by the WHO, OIE and FAO [85], could be part of a solution in the short term to minimise further pandemic outbreaks [84]. The focus of GLEWS+ is, however, on early detection of diseases when an outbreak has already occurred, and other networks, such as the global influenza surveillance and response system of the WHO, are restricted to one pathogen [86]. Carroll et al. [86] therefore call for the establishment of a collateral global early warning viral surveillance network embedded within the United Nations. Such a viral surveillance system is envisaged to carry out active, prophylactic screening for viral pathogens in known hotspot areas of zoonotic disease emergence in wild and livestock animals and humans before outbreaks occur [86]. To this end, methods of big data analysis, bioinformatics and metagenomics could be essential tools to identify hot spots of disease emergence and for rapid detection of pathogens as part of an interdisciplinary One Health approach [87]. In a general sense, ten Have [88] advised applying global governance as implied by the One Health principle to surveillance of human connections with animals, particularly in the bioindustry. Taken together, governmental, particularly legal, regulations have been found to be the prevailing instruments for implementing actual and proposed responses to the crisis affecting factory farming.

\subsection{Business and Private Sector}

Alternative protein sources, such as pulses, algae, plant-based meat, insect-based food and cultured meat [89], have been proposed as substitutes for meat from industrial agriculture, thus providing a possible solution to zoonotic risk. Examples of large food companies that have, albeit already before the pandemic, started to add plant-based products to their portfolios, employ vegetable proteins in addition to meat or employ a fermented fungus as a substitute for meat, are quoted by Greger [66]. However, as pointed out by Rzymski et al. [79], cultured meat in particular and, to a lesser extent, insect-based food harbour superior potential over plant-based products to substitute meat from livestock because of their nutritional and organoleptic properties that come closest to conventional meat. Cultured meat production involves growing animal muscle cells from stem cells using controlled laboratory procedures of cell culture and tissue engineering that enable a faster supply of the edible product than by farming and slaughtering animals and offer the possibility of targeted nutritional modifications, and though the process requires sterile conditions, alternatives to the use of antibiotics are available [54,79]. Nevertheless, research and development must still address a number of technological challenges related to the production process of cultured meat that remain to be tackled and overcome by manufacturers to allow for its mass production [54,79].

For maintaining a high standard of biosecurity, biotech companies assume a central role in the development of vaccines to known diseases affecting livestock such as SARSCoV-2 in mink [54]. Another role of business is the potentially powerful influence of food retailers, such as supermarkets, on the food animal industry even in the absence of legal regulation [59]. As for poultry products in the UK, it has been proposed that supermarkets quit marketing chicken from intensive farming and abide by a long-term scheme to sell only poultry from organic and free-range farming [59]. This measure is advised to go along with a general reduction and increase, respectively, of offered animal- and plantbased products and with a commitment to adhere to a self-regulatory initiative ensuring certain standards of welfare for farmed chicken (the "Better Chicken Commitment"), which was already adopted by food chains and retailers like KFC and Marks \& Spencer [59]. Finally, divesting private capital from companies involved in factory farming and avoiding 
investments in such companies will make a significant contribution [73]. Concomitantly, private investments are advocated to be directed to food systems that exhibit sustainable farming practices instead of dependence on intensive animal farming in order to reduce zoonotic risk [90]. In general, the role of business responses affecting industrial animal farming was found to be moderate relative to the gamut of governmental regulations.

\subsection{Consumers}

COVID-19-related responses affecting industrial livestock farming that emanate from civil society are most importantly associated with altered consumer behaviour and lifestyle changes with respect to food animal products. In this regard, dietary changes forced upon consumers by confinements during the crisis must be separated from responses based upon awareness for (or ignorance to) the potential zoonotic risk associated with animal products. As for dietary behaviours during social lockdowns due to the fact of COVID-19, studies from all over the world have put forth heterogeneous results. This is mirrored in a review on the topic that shows that several studies reported healthier diet practices, while many others found an increase in adverse dietary choices and habits [91]. For example, a survey among Polish adults during quarantine in spring 2020 revealed increased consumption of low-fat meat and eggs but decreased processed meat intake except in respondents adhering to an unhealthy dietary pattern whose consumption of processed meat also rose compared with before quarantine [92]. Likewise, surveyed during the first lockdown period in 2020, young people aged 10-19 years from several southern European and South American countries exhibited a significant increase in consumption of vegetables, legumes and fruits but no change in processed meat intake except in boys who consumed slightly more meat [93]. On the contrary, besides increased consumption of vegetables, legumes and fruits, a lowered intake of various kinds of meat was also observed in two studies among Spanish adults during confinement in spring 2020 [94,95], which was associated with a shortage of meat stocks in supermarkets and grocery stores during the lockdown period [95]. Indeed, a global decline in meat consumption occurred during the pandemic in 2020 [54,96], which is mainly attributable to both the production and the demand side due to the market and supply chain disruptions, consumers' worse economic situation [96] as well as closures of restaurants where more meat is usually consumed than at home [97].

However, apart from economic and logistic constraints of food availability, considerations of food safety based on awareness of the roots of zoonotic pandemics could also play a role in curtailed meat intake. In this regard, an increase in demand for organic products in high-income countries as well as a steep rise in sales of plant-based meat products in the US noted during spring 2020 were partly traced to consumers' food safety concerns [97]. By the same token, Lee [98] reports on increasing consumers' interest in products from sustainable rather than industrial farming and in plant-based meat alternatives. In addition, the gained popularity of veganism during the pandemic [99], a nutritional style characterized by a radical exclusion of all animal products from the diet, could indicate many consumers' conscious avoidance of products related to industrial farming. This is exemplified by the results of market research in the UK that for a quarter of young adults aged 21-30 years, a vegan diet has become more appealing because of COVID-19 [99,100].

By contrast, several survey studies cast doubt on impressions of changing dietary patterns such as one among adults in the UK on their perceptions of potential responses to prevent future pandemics [101]. In this study conducted during the COVID-19 crisis in 2020, participants ascribed the highest priority to reactionary responses of epidemic preparedness by politics, followed by preventive responses related to restriction of wildlife trade, and rated as least important preventive solutions related to restriction of factory farming and global meat consumption [101]. Moreover, the importance of factory farming and meat consumption was particularly low for participants committed to high meat consumption. Even when, before the survey, scientifically based information was provided to the participants about equal zoonotic risk by wildlife markets and factory farming, 
the endorsement of measures to curb factory farming and global meat consumption was still significantly below that of reactionary responses especially amongst those highly committed to meat but not of measures to restrict wild animal markets [101]. The authors concluded that zoonotic risk posed by factory farms is deliberately ignored particularly by those who eat much meat [101]. A further survey from the US examined the impact of COVID-19-related messages about the connection between factory farming and pandemic risk or about the health risks farm workers are exposed to in factory farms on study participants' intentions to reduce meat consumption [102]. Though changing participants' beliefs, these messages did not translate into significantly stronger behavioural intentions to consume less meat and try plant-based meat alternatives or to encourage others to do so more than "traditional" messages addressing animal welfare, environmental impacts, and health effects of meat consumption [102]. Moreover, among the examined messages, it was health issues that were most strongly associated with trusting the messengers, i.e., individuals or organisations that advocate reducing meat intake [102]. A further survey study compared attitudes towards plant-based and cultured meat in Belgium at the beginning of 2019 and in mid-2020 after the first coronavirus wave [103]. The results demonstrated that a surprisingly high percentage of participants expressed their probable or definite intention to buy cultured meat, particularly the younger ones, amounting to approximately $40 \%$ of respondents overall in each year, though devoid of a significant change from 2019 to 2020 [103]. However, satisfaction with plant-based meat alternatives, which was likewise pronounced among younger consumers, slightly but significantly increased from 2019 to 2020 [103].

Among COVID-19-induced calls for reduced (excessive) consumption of animal products to mitigate the zoonotic risk due to the fact of factory farming [66,75], Jones [61] elaborates on the argument by postulating a moral obligation on the part of the consumers not to buy and eat most meat. In detail, he claims that animal products can be graded according to their zoonotic disease risk, consumption of the riskiest of which, such as meat from wildlife markets and factory farms but also farmed fish (due to the massive use of antibiotics), represents complicity in collective harm. This view also implies the moral permissibility to consume animal products with minor or lacking zoonotic risk like wild-caught fish or meat from free-range animals from organic farms [61]. However, also uncertainty and doubt have been expressed over the magnitude of the impact and the sufficiency of reduced meat consumption, albeit desirable with respect to personal health benefits, for decreasing zoonotic risk [54,79]. In this regard, we are advised to quickly adopt eating plant-based and cultured meats that have been highlighted as safe sources of protein in place of food from factory farms [20].

Table A1 (Appendix B) summarises the findings of the present review classified according to thematic categories.

\section{Discussion}

In accordance with the purpose of the present study, an array of proposed and actual responses to the COVID-19 crisis with relevance for zoonotic risk of industrial animal farming could be identified. Based thereon, ten thematic categories were discerned, representing diverse fields of potential policy action. Amongst those, proposals for improved biosecurity measures and better health of farmed animals prevail, but responses and proposals aimed at curtailing meat consumption and at the development and propagation of alternative meat, bearing vastly reduced or no zoonotic risk, also appear prominently in the identified core literature. Upon matching proposed and actual responses with pre-defined societal actors that are endowed with distinct instruments for zoonotic risk mitigation and achieving solutions, it was found that overall, suggestions to be implemented by governmental regulation predominate, and that the private and business sector is underrepresented. Thus, all research questions of the study could be appropriately answered. Key aspects of the findings and implications to anticipate developments beyond the COVID-19 crisis and to design viable policies are discussed below. 


\subsection{Thematic Fields for Policy Action}

The number of articles assigned to each thematic category may be roughly reflective of the relative importance attached to it. Provisions for improved biosecurity and pathogen surveillance on farms suggest themselves most straightforwardly as first-line measures of risk mitigation as well as if the present-day food system is not called into question. Of note, most other thematic fields identified herein imply abatement or elimination of industrial animal farming through dietary change or legal or economic regulation. Indeed, given the projected future increase in meat demand [38] and that SDG (sustainable development goal) 2 ("zero hunger") is compatible with intensive food animal production by factory farms, a preponderance of recommendations for enhanced biosecurity comes of no surprise. Partly underlying this finding might be a notion that compared with extensive small-scale farming, zoonotic risk from intensive industrial farming is lower because the confinement of animals minimises their contact with wildlife, provided that factory farms adhere to good biosecurity standards [34,35]. In this regard, Alvseike et al. [104] have assumed lower zoonotic risk per $\mathrm{kg}$ animal product from large-scale vs. small-scale production, and that the next pandemic will probably not originate from intensive livestock farming. However, important aspects argue against such a view, i.e., the substantial magnitude of any disease outbreak amongst densely crowded livestock that generates favourable conditions for genetic evolution of pathogens, the worse health status of animals in factory farms compared with free-range livestock, the environmental contamination with animal waste as well as high human infection risk during transportation and slaughter $[34,36,73]$ (cf. Introduction). Furthermore, antibiotic use per animal on factory farms exceeds that in animals kept in more natural conditions [36], and poor compliance with biosecurity standards occurring in the factory farming industry [73], as reported for example from Australian chicken farms [105], has been traced to pursuit of profit and lack of regulation [36]. In addition, Graham et al. [23] have shown that the risk of avian influenza outbreaks was not decreased in commercial poultry farms vs. backyard production and that even improved biosecurity measures were not necessarily associated with a decrease in avian influenza risk, whereas reduction of stock density was.

Consumers' COVID-motivated changes in dietary habits were revealed as a further salient topic in which effects related to immediate constraints of the crisis were not considered as relevant literature. In this respect, altered dietary patterns due to the lockdowns were regarded as a direct impact of the crisis rather than conscious societal responses. However, reported changes in global meat consumption were considered relevant because of a potential contribution of factors of awareness for food safety and zoonotic threat. In this category, suggestions for information campaigns to promote diets with reduced or lacking zoonotic hazards were also included. It could hence be argued that this topic is merged with the topic of taxation of animal products, because levies are likewise aimed at influencing consumers' dietary habits; however, frequent proposals for a meat tax justified the delimitation of a category "taxation of animal products" of its own. It should furthermore be emphasised that thematic categories are not independent of each other. For example, policies regulating or prohibiting factory farming, represented by two fields of action of their own, could influence or be influenced by other areas like dietary changes, introduction of alternative meat or strengthening the sustainable farming sector. Moreover, consumers' adoption of alternative meat always goes along with dietary changes, whereas this need not be the case vice versa. Finally, the topic of human population control and degrowth to curb demand for meat from industrial farms as a response to COVID-19 was based on solely one article and might therefore be regarded of minor importance. In support of the potential general relevance, another paper retrieved by the additional literature search in this category (cf. Appendix A) advocates stopping high population growth rates for preventing future pandemics [106]. Although the article acknowledges factory farming as one risk factor for zoonotic pandemics, this recommendation is given in the context of biodiversity loss and ecosystem destruction [106], which is why this paper was not included in the body of relevant literature. 


\subsection{Actors' Roles}

Hard regulation by law certainly plays a pivotal role in the prevention of zoonotic pandemics originating from factory farms. Risky conditions on farms can be abolished or effectively controlled by enhancing biosecurity by legal enforcement. For example, a phase-out of the use of antibiotics as growth stimulants in animal feed was decided by the European Union in 2003 leading to a total ban as of 2006 [107,108]. In Denmark, several actions and bans on the non-therapeutic use of antimicrobials preceded the EU-wide prohibition leading, in fact, to waning resistance in bacteria [108], and measures were taken to promote biosecurity, disease monitoring and animal health on farms to maintain production levels after the ban [108]. Indeed, an increase in Danish pig productivity was seen even after the complete discontinuation of antibiotics as growth promoters in 2000 [109], demonstrating the feasibility of industrial farming without their use. Similarly, in the US, the use of antibiotics for livestock farming was restricted by law as of 2017, rendering their administration for growth promotion illegal and stipulating prescription by a veterinarian for other use such as disease prevention which is still permitted [110]. Ever since there has been no indication of a negative implication for animal growth [110], and an overall decrease in antimicrobial resistance from 2016 to 2017 was noted [110]; however, the reduction in total use of antibiotics has partly been offset by enhanced therapeutic prescription [110]. Lamentably, non-therapeutic application of anti-microbials in animals is still unprohibited or poorly regulated in many parts of the world, including numerous developing countries [111]. Limited financial resources are an important factor for insufficient regulation of biosecurity and implementing surveillance measures commensurate with the growing intensification of animal husbandry in these countries [63,112].

Recurrent SARS-CoV-2 infections in mink eventually resulted in the prohibition of mink farming in the Netherlands. As Peters [57] points out, a ban in one country, however, bears the risk of stimulating business in others devoid of a ban. As per her suggestions, solutions to prevent this effect include the prohibition of imports, lack of demand by consumers for mink products or a global ban [57]. The legal response by the Dutch government was driven by an immediate and palpable threat to human health. It is therefore unlikely that other sectors of livestock farming will face closure as long as they are not perceived as high-risk sites for an impending epi- or pandemic given the wildlife origin of COVID-19. In view of a desirable transformation towards a sustainable agricultural system without factory farming, it must, however, be borne in mind that adverse issues might arise. For example, organic vs. intensive beef production has been reported to entail a $22 \%$ increase in land use per production unit [113], and converting global agriculture totally to organic would result in up to a $33 \%$ increased land use and up to $15 \%$ increased deforestation by 2050 , unless food wastage and consumption of animal products are radically curtailed [114]. In addition, banning wildlife trade, markets and consumption globally, as frequently advocated (e.g., [42,43]), could be problematic especially regarding local and indigenous peoples' food security and drive those deprived of wild meat towards consumption of products from industrial farming which would stimulate habitat destruction and deforestation as zoonotic drivers [19,71,72]. However, given that the reliance of most countries on wild meat is very low, not exceeding $5 \%$ or even less of their total consumption of animal protein [72], a global ban on wildlife trade could be regarded as not implying a drastic overall rise in industrial animal farming, also because not all wild meat would have to be substituted with products from factory farms. On the other hand, regions with high consumption of wild meat, such as in many African countries, would arguably be heavily impacted by such a ban, entailing undersupply of protein and exacerbated food insecurity, and ensuing land-use change, habitat destruction and species extinction due to the increased livestock production [72].

Taxation as an instrument to attenuate consumption of animal products, in particular meat, and to account for their externalities, appeared as a frequent proposal in the present review. A tax on animal products or specifically on meat could be imposed either directly on consumers $[34,61,74,75]$ or on the production side $[62,75]$. Whereas taxing factory farming 
harbours the risk that imports from other countries circumvent taxation as long as there is no uniform international regulation, levies on animal products imposed on consumers would apply to all sales in a country. In terms of a "zoonotic tax", different tax rates might apply according to the zoonotic risk associated with varying conditions of farming. Similar arguments have been put forth by Treich [115], who claims that regulation on the demand side (i.e., consumers) is more efficient than regulating producers in factoring in overall externalities of meat production. Regulation of meat consumption might probably face, however, strong opposition by meat producers as well as consumers [116]. Indeed, a carbon tax on meat, integrating its environmental externalities, has hitherto not been introduced by any country in the world [115], but the idea to impose a carbon tax on meat and dairy has recently been advanced by the UK government [117]. Tax revenues could be utilised to fund earmarked subsidies for zoonotic risk prevention such as supporting sustainable farming, public campaigns for less meat-based diets or companies in the alternative meat sector. Product labelling as a further tool to regulate the demand side by facilitating consumers' informed food choices and to stimulate manufacturers' and retailers' shift to sustainable food production [82] might have its pitfalls. As Parker et al. [118] point out, labelling of meat products might be conveying reductionist information and misleading claims and be susceptible to greenwashing, unless standards are set by governmental meta-regulation, involving multiple stakeholders.

The necessity of a stringent legal framework for farm biosecurity notwithstanding, farms are responsible for compliance with the rules such as safe-guarding hygienic standards. Moreover, beyond legal regulations, COVID-19 could be a starting point for initiatives by the livestock sector and food retailers towards improving animal welfare and mitigating infectious disease and antimicrobial resistance risk. In Denmark in 1995, it was the farmers' initiative to stop administration of growth promoting anti-microbials after high levels of resistant bacteria had been discovered in chickens from industrial farming [108] and development but importantly also deployment of antibiotic substitutes, such as plant bioactive compounds, probiotics, antimicrobial peptides, acidifiers, and functional oligosaccharides, could restrain overuse of antibiotics but are currently lacking equal efficacy [119]. Furthermore, food retailers and food companies as key actors along the food supply chain play a central role, e.g., by excluding unsustainably manufactured goods from their portfolio of products [59]. A case study from Germany on the motives of retailers to market pasture-based beef identified as main factors both meeting perceived consumers demands as extrinsic, and concern for animal welfare as intrinsic motives [120]. Even though the importance of retailers' personal interest in animal welfare is highlighted in this study, results nevertheless demonstrate the powerful influence of consumer behaviour, implying that a change to sustainable food products must be initiated by the demand side. Accordingly, food retailers show reservation towards innovative food products unless they perceive clear benefits of these products for consumers [121]. To actively stimulate demand for organic animal products or vegetarian or vegan goods, business stakeholders (e.g., farmers, retailers and food companies) could launch marketing campaigns emphasising that in face of COVID-19, their products lack zoonotic risk as opposed to food from factory farms. However, caution is warranted due to the possible greenwashing of such campaigns, and because COVID-19-related messages on pandemic risk by factory farming have not proven to be more effective in generating intentions to reduce meat consumption than, for example, messages related to the health benefits of a low meat diet [102].

Demand for animal products is the root driving force dictating the size of the industrial livestock farming sector and the associated zoonotic risk. The immediate impact of the pandemic has entailed a downturn in global meat consumption [96], presumably mainly imposed by constraints of food availability rather than awareness of the zoonotic origin of the pandemic and concerns over factory farmed animal products. On the other hand, eating meat as a source of COVID-19 was identified as one major topic in COVID-19related user conversations on the social media platform Twitter, where non-vegetarians were blamed for the outbreak of the pandemic [122]. Interestingly, the blame was not 
restricted to consumption of wild meat in this study despite the presumable wildlife origin of COVID-19. Indeed, as pointed out by Attwood \& Hajat [97], previous zoonotic events instigated noticeable, however, transient changes in consumer behaviour following the outbreaks. For example, Chinese consumers' demand for poultry dropped in the aftermath of the avian influenza outbreak in 2013 due to the fact of food safety concerns, and beef sales sustainably declined for many years following the discovery and occurrences of BSE (bovine spongiform encephalopathy) in the 1980s and 1990s [97]. In the case of BSE, no effect of decreased consumption of meat other than beef was noted though [97], and it can be assumed that consumers simply replaced the "problematic" type of meat with other meat, e.g., beef with pork. Research by Dhont et al. [101] moreover suggests that probably as a result of COVID-19, consumers in a Western civilization rate factory farming and global meat-eating habits as less important zoonotic risk factors than wildlife trade and eating wild meat and might contextualize zoonoses mainly with "exotic" dietary habits and wet markets, therefore not impugning their own dietary behaviours. Consistently, messages stating the zoonotic risk of factory farming communicated to survey participants during the COVID-19 pandemic did not elicit particularly strong intentions to reduce meat intake [102]. Based on available evidence, a lasting impact of the pandemic on boosting low-meat and no-meat diets is hence not expected, a conclusion shared by Halabowski and Rzymski [54], who state that COVID-19 is unlikely to alter dietary choices with respect to meat from livestock farming. At best, a marginal increase might be observed in the portions of vegetarians, currently accounting for an estimated percentage of $5-10 \%$ globally [123], and of vegans, not more than approximately $2 \%$ of the population depending on the country [124]. Without a sustainable COVID-19-related effect, future worldwide meat consumption could thus likely follow previous FAO projections anticipating a rise by $75-80 \%$ from 2005 to 2050 , driven by increasing welfare and population growth $[38,125]$. In this forecast, the highest relative increase is expected for South Asia, and particularly in India, which boasts a long tradition of vegetarianism, meat consumption is predicted to sextuple, yet to amount to merely $6.5 \%$ of the global consumption in 2050 [125]. Despite slowing growth rates of meat demand, Western industrialised countries and China are expected to still account for the bulk of global meat consumption by mid-century (based on data in [125]). Contrary to the trend, younger people seem more inclined to reducing meat consumption as a response to the COVID-19 crisis as suggested by negative attitudes towards game meat in young relative to older Chinese adults [39] and the COVID-19-related gain of the attraction of a vegan diet among young adults in the UK [99,100]. Relatedly, propensities to perceive factory farming and global meat consumption as pandemic risks and to endorse a preventive solution targeting factory farms and global meat consumption were both slightly but significantly inversely correlated with age in a study by Dhont et al. [101].

Achieving consumers' widespread adoption of alternative proteins replacing conventional meat as a potential solution to zoonotic threats by factory farming faces several challenges. First, consumer acceptance is low compared with conventional meat, being highest for plant-based alternatives, whereas cultured meat is moderately preferred and insect-based food least accepted [89]. Nevertheless, insects are part of diets mainly outside the Western world, particularly in the tropics and subtropics in countries like Mexico, Zimbabwe, and Thailand [126], and as many as $80 \%$ of the world population are used to eating insects [126], thus low acceptance, refusal or even disgust for insects as food are culturally dependent. While plant-based proteins possess limited value to replace conventional meat because of organoleptic and nutritional distinctness and because many meat eaters simply refuse to change their diet [79], subjects committed to high meat consumption are particularly receptive to cultured meat [89], presumably owing to its property and potential to closely mimic real meat in terms of taste, texture, smell, and nutrients. In contrast, insects usually represent no attractive option to consumers irrespective of their meat eating habits [89]. Intriguingly, Bryant and Sanctorum [103] reported intention to buy cultivated meat products in $40 \%$ of participants in their study in Belgium, and Dempsey 
and Bryant [127], in a survey among Chinese consumers conducted right before the onset of COVID-19, found even a 70\% willingness to try and a 58\% willingness to buy cultured meat, and a 34\% willingness to replace natural meat with it. In another survey, 30\%, 59\% and $56 \%$ of consumers in the United States, China and India, respectively, were very or extremely likely to purchase cultured meat [128].

Besides consumer acceptability, technological challenges would still have to be overcome and uncertainties clarified for both insects farmed as food and cultured meat, requiring joint endeavours by businesses and governments to invest in research and development activities. Farmed insects, most importantly, carry a risk of acting as vectors for bacteria, viruses and parasites with potential pathogenicity for humans, although it has been claimed that zoonotic risk is low and, in addition, there are issues with food allergens [79,129]. As for the production of cultured meat, animals would still be utilised for extraction of embryonic or muscle tissue stem cells which are thereafter cultured, propagated and differentiated in vitro (e.g., [115]). For cell culture growth, animal-origin-free media have been developed as substitutes for foetal bovine serum (FBS) as a traditional growth medium harvested from dead calves, and maintaining sterile conditions seems possible without the use of antibiotics $[79,130]$. Problematic issues yet to be tackled include growth promoters like hormones added to the culture medium that might exert adverse effects on human health [130], the upscaling of the procedure for cost-effective industrial production and the high energy consumption of the production process $[79,115]$. In terms of greenhouse gas emissions, in vitro meat could thus fare worse than insect-based food and, as a matter of debate, maybe also compared with industrial livestock products [115,131], but mitigation is possible by the use of renewable energy [79]. Both alternatives are associated though with reduced land use and decreased water consumption relative to intensive livestock production $[79,115,129]$. As a possible implication of the future widespread replacement of conventional with cultured meat, negative impacts on livestock-based economies in developing countries have been addressed [131], which would arguably also occur with other meat alternatives if these gained increased popularity. Moreover, alternative meat sources do not solve health-related problems of high-meat diets, and people who now abstain from meat mainly for ethical reasons might then be inclined to ingesting more meat from "clean" sources. Cell-based meat production offers the possibility for targeted modification though, for example, to decrease potentially unhealthy compounds such as saturated fats $[79,115]$.

\subsection{Future Perspective}

Relying on the identified COVID-19-related responses and proposals, as well as critical appraisal thereof, is there a viable and sustainable perspective emerging for prevention of future zoonotic pandemics associated with industrial animal farming, and which policies are the most apt ones? Prohibition of intensive animal farming practices is not a sustainable policy due to the anticipated increase in land use and deforestation caused by extensive farming unless accompanied by a marked decline in demand for animal-based products. However, an eminent and sustained effect of the crisis resulting in a continuing global decrease in meat consumption is doubtful based on the evidence presented herein, and it remains to be seen whether a possible effect of the crisis on the younger generations is able to antagonise the predicted rise in meat demand. To discourage consumption of animal products from industrial farming and to foster agro-ecological food production and alternative protein sources, economic regulation of the demand side materialised as "zoonotic risk tax" or "zoonotic tax" imposed on consumers as suggested by Espinosa et al. [34] can be an appropriate avenue, to be implemented preferably in a larger context, e.g., as an EU-wide tax, defying possible resistance by meat producers and consumers alike [116]. This tax could be accompanied by a governmental (e.g., EU-wide) product label stating the farming method [82]. Importantly, imposing a zoonotic tax should be distinct from a carbon tax on meat [117] because of the risk of the latter of unintendedly stimulating intensive poultry and pig farming owing to their smaller carbon footprints 
relative to beef farming [73]. Ideally, the zoonotic tax amount would differ by the degree of zoonotic hazard associated with a certain product, thus reflecting the approach by Jones [61] of an ethical obligation to avoid meat as per its zoonotic risk. Hence, meat from organic agriculture would not be subject to zoonotic taxation as opposed to farmed fish and products from intensive livestock farms. Earmarked revenues earned through this tax should be utilised for subsidising products from organic farming to be available to consumers for lower prices, and for funding research and development activities to promote alternatives to conventional meat (e.g., [34,78]). This would aid in overcoming technological barriers to cell-based meat production [80] and towards optimisation of the production process to meet consumers' desires and curb consumption of resources to enable quick marketability of sustainable cell-based food. In regions where insects are already popular as food, large-scale insect-based food production could be subsidised. In general, however, cultured meat is preferable over insect-based food due to the potential zoonotic risk associated with insect farms. Until the goal of phasing out or limiting factory farming by such policies is attained, ensuring rigorous biosecurity standards (e.g., hygiene measures, isolation from wildlife $[23,47]$ ) in conjunction with efficient local and global disease monitoring using sophisticated methods [87] and best possible animal welfare guided by the One Health principle, importantly also in low-income countries, will be of the utmost importance to help to prevent the next pandemic from an industrial animal farm.

\subsection{Limitations and Strengths}

This work has several limitations but also strengths. First, ecological risk factors affecting pathogen transmission from wildlife to livestock [18], including habitat destruction and deforestation [13], were not accounted for. These may act as risk factors also for infections in industrial farms and ensuing zoonotic outbreaks as described, for example, for the Nipah virus emergence in Malaysia [22]. This topic did not show up in the identified literature but might have been missed because ecological causes of zoonoses were not a focus of the present study. Another potential limitation might concern the use of Google Scholar as an exclusive search engine instead of using also other search engines and databases. However, owing to the wide range and variety of identifiable literature, we regarded Google Scholar as an ideally suited search tool for this scoping study. Next, the scope of the search for articles of the core literature was specified by using combined search terms for the aspect of zoonosis in order to avoid mostly locating literature stating that COVID-19 is a zoonotic disease for which also factory farming plays a role, but devoid of recommendations or actions to prevent future outbreaks. Subsequent further category-specific screening of the literature using a broader scope for the zoonotic aspect yielded relatively few additional articles containing new information. It can hence be assumed that all relevant responses, proposals, concepts and ideas were captured by the applied search strategy. Another potential limitation concerns the fact that most studies reporting consumer responses referred to the first lockdown period in many countries in spring 2020, so it could be speculated that outcomes might have been different had these studies been extended to include a longer time span. Furthermore, online newspapers and personal webpages not accessible via Google Scholar but via web search were not considered as sources, just as blog post entries that were retrieved via Google Scholar, to prevent drawing conclusions based on anecdotal reports and newspaper articles reflecting journalists' personal impressions and opinions. This could be interpreted both as a weakness and a strength of the present study. Presumably, more actual responses to the crisis, such as local food initiatives aimed at curbing meat consumption, would have been identified had such sources been included in the relevant literature. These were, however, considered as evidence when referenced in the identified relevant literature. Eventually, since the main focus of the present study was on zoonotic risk prevention, aspects of animal ethics and scrutiny of the sustainability of policy proposals in terms of ecological impacts and carbon footprint might have been missed out. 


\section{Conclusions}

In conclusion, the COVID-19 pandemic, albeit deemed of wildlife origin, has stimulated a spectrum of responses affecting mitigation and prevention of zoonotic risk associated with industrial animal farming. These include suggestions for action and policies by experts and scholars, measures such as laws, as well as consumers' behaviours, attitudes and beliefs pertaining to ten identified fields of (potential) policy action and (to be) implemented by distinct stakeholders. In the present review, strengthening biosecurity and measures to curb consumption of animal products were found the prevailing topics, and governmental regulation seems to assume a key role for efficient future policies. It is improbable that consumers will, as a consequence of the COVID-19 pandemic, reduce the intake of animal products from industrial farming on a large scale. Therefore, one feasible way to sustainably curb the zoonotic risk of factory farming can be an earmarked zoonotic risk tax on the demand side, revenues of which are to be deployed for subsidising sustainable farming and research on and development and marketing of alternative meat, preferably cultured meat. This long-term strategy, however, must be pursued along with enhanced efforts to guarantee that biosecurity systems work well in industrial farms as a strategy for short-term risk reduction. Recent avian influenza outbreaks due to the emerging subtype H5N8 in poultry farms around the world leading to the first human infections in Russian farm workers by end of 2020 [132] are just a further reminder that action is urgently needed. Facilitated by disease outbreaks in crowded farming conditions, genomic mutations and genetic exchange with other strains could endow a pathogen with the capability to efficiently spread also in humans. If combined with case fatalities in humans of the H5N1 avian influenza virus (i.e., an estimated 14-33\% [133]), the ensuing pandemic would be one of unprecedented scale. Understanding COVID-19 as a signal for a sustainable change in our food system and for timely action could spare humanity such a calamity.

Author Contributions: Conceptualization, W.B. and C.F.; methodology, W.B. and C.F.; validation, W.B. and C.F.; formal analysis, W.B.; investigation, W.B. and C.F.; resources, W.B. and C.F.; data curation, W.B.; writing—original draft preparation, W.B.; writing-review and editing, W.B. and C.F.; visualization, W.B.; supervision, C.F.; project administration, C.F. Both authors have read and agreed to the published version of the manuscript.

Funding: This research received no external funding.

Data Availability Statement: The data that support the findings of this study are available from the corresponding author upon reasonable request.

Acknowledgments: The authors acknowledge open access funding provided by BOKU Vienna Open Access Publishing Fund for covering publication fees, which had no role in funding the research.

Conflicts of Interest: The authors declare no conflict of interest.

\section{Appendix A}

Search term combinations in Google Scholar for each of the ten thematic categories, including a total number of hits and a number of relevant records between 1 January 2020 and May 2021.

Biosecurity and animal health:

COVID-19 AND zoono* AND prevention AND “animal health" AND vaccin* OR antibiotics OR "biosecurity OR biosafety measures" OR "pathogen OR disease surveillance OR monitoring" AND "livestock production" OR "industrial animal farming" OR "industrial food animal production" OR "intensive animal husbandry" OR CAFO OR "factory OR livestock farming".

149 hits on 16 May 2021; 2 additional relevant articles: Carroll et al., 2021 [86]; Sikkema \& Koopmans, 2021 [87].

Dietary changes: 
COVID-19 AND "consumer awareness" AND "nutritional OR food OR dietary OR "food consumption" habits OR behavio* OR choice" AND meat OR "animal products" OR vegan OR vegetarian AND "livestock production" OR "industrial animal farming" OR "industrial food animal production" OR "intensive animal husbandry" OR CAFO OR "factory OR livestock farming".

59 hits on 17 May 2021; 1 additional relevant article: Ghislain, 2021 [82].

Since modification of animal products-related food habits is not necessarily tied to factory farming, an additional search performed on 28 May 2021, using the same terms but omitting search terms for factory farming ("livestock production" OR "industrial animal farming" OR "industrial food animal production" OR "intensive animal husbandry" OR CAFO OR "factory OR livestock farming") yielded 188 hits but still only one additional relevant article (Ghislain, 2021 [82]).

Alternatives to animal products:

COVID-19 AND zoono* AND "cultured OR cell-based OR cultivated meat" OR entomophagy OR "insect-based food" OR "plant-based meat" OR "alternative proteins" AND "livestock production" OR "industrial animal farming" OR "industrial food animal production" OR "intensive animal husbandry" OR CAFO OR "factory OR livestock farming".

73 hits on 18 May 2021; 3 additional relevant articles: Bryant \& Sanctorum, 2021 [103]; Niemiec et al., 2021 [102]; Smith et al., 2021 [80].

Prohibition of factory farming:

COVID-19 AND zoono* AND prohibit OR prohibition OR ban AND "industrial livestock production" OR "industrial animal farming" OR "industrial food animal production" OR "intensive animal husbandry" OR CAFO OR "factory farming" OR "industrial livestock farming".

77 hits on 21 May 2021; 1 additional relevant article: Open Cages et al., 2020 [59].

Taxation on animal products:

COVID-19 AND "taxation OR tax OR levies on meat" OR "taxation OR tax OR levies on animal products" OR "meat tax OR taxation" AND "livestock production" OR "industrial animal farming" OR "industrial food animal production" OR "intensive animal husbandry" OR CAFO OR "factory OR livestock farming".

22 hits on 18 May 2021; 0 additional relevant articles.

Economic regulation of factory farming:

COVID-19 AND zoono* AND regulat* OR "invest* in" OR fund* OR tax* OR subsid* AND "industrial livestock production" OR "industrial animal farming" OR "industrial food animal production" OR "intensive animal husbandry" OR CAFO OR "factory farming" OR "industrial livestock farming".

91 hits on 20 May 2021; 0 additional relevant articles.

Support for sustainable farming:

COVID-19 AND zoono* AND "sustainable OR organic farming" OR agroecology AND "industrial livestock production" OR "industrial animal farming" OR "industrial food animal production" OR "intensive animal husbandry" OR CAFO OR "factory farming" OR "industrial livestock farming".

35 hits on 22 May 2021; 1 additional relevant article: Lymbery, 2020 [17].

One Health approach:

COVID-19 AND zoono* AND "One Health" AND "industrial livestock production" OR "industrial animal farming" OR "industrial food animal production" OR "intensive animal husbandry" OR CAFO OR "factory farming" OR "industrial livestock farming".

62 hits on 28 May 2021: 0 additional relevant articles.

Ban on wildlife trade: 
COVID-19 AND "wildlife trade" AND consumption AND "ban OR prohibition" AND "livestock production" OR "industrial animal farming" OR "industrial food animal production" OR "intensive animal husbandry" OR CAFO OR "factory OR livestock farming".

81 hits on 18 May 2021; 0 additional relevant articles.

Human population degrowth:

COVID-19 zoono* "human population growth OR control" "industrial livestock production" OR "industrial animal farming" OR "industrial food animal production" OR "intensive animal husbandry" OR CAFO OR "factory farming" OR "industrial livestock farming".

8 hits on 28 May 2021: 0 additional relevant articles.

\section{Appendix B}

Table A1. Summary of the relevant literature and content classified according to topics.

\begin{tabular}{|c|c|c|}
\hline Reference & Relevant Content & $\begin{array}{l}\text { Main Actors for } \\
\text { Implementation, Type } \\
\text { of Regulation }\end{array}$ \\
\hline \multicolumn{3}{|c|}{ Biosecurity and Animal Health } \\
\hline Aigner et al., 2020 [53] & $\begin{array}{l}\text { Proposal to identify and collect microbes, such as viruses, known to be } \\
\text { shared by livestock and humans }\end{array}$ & mainly legal \\
\hline Andrews, 2020 [60] & $\begin{array}{l}\text { Proposal for selective breeding of farmed animals with stronger immune } \\
\text { systems to decrease their vulnerability }\end{array}$ & $\begin{array}{l}\text { mainly legal; } \\
\text { governmental- } \\
\text { economical; } \\
\text { business/private }\end{array}$ \\
\hline $\begin{array}{l}\text { Broom, } 2020 \text { [48]; Petrovan } \\
\quad \text { et al., } 2020 \text { [47] }^{1}\end{array}$ & $\begin{array}{l}\text { Proposal for various universal biosecurity measures (protective clothing } \\
\text { and training for farm workers, controlling access of visitors and vehicles, } \\
\text { separation of livestock from wild animals, preventing food and water } \\
\text { contamination, limitation of the stocking densities of animals to } \\
\text { contribute to their welfare and enhance their immune systems, } \\
\text { regulation of international animal transports with enforcement of } \\
\text { detailed health checks); reduction of antibiotic overuse (Broom, } 2020 \text { [47]) }\end{array}$ & mainly legal \\
\hline Carroll et al., 2021 [86] ${ }^{2}$ & $\begin{array}{l}\text { Suggested establishment of a global early warning viral surveillance } \\
\text { network with focus on hotspots of disease emergence embedded within } \\
\text { the United Nations }\end{array}$ & $\begin{array}{l}\text { intergovernmental/supra- } \\
\text { national }\end{array}$ \\
\hline Ellwanger et al., 2021 [50] & $\begin{array}{l}\text { Reducing and controlling contact between humans and livestock animals } \\
\text { as an important factor for zoonotic disease prevention }\end{array}$ & mainly legal \\
\hline Espinosa et al., 2020 [34] & Proposal to incentivise early reporting of disease outbreaks by farms & governmental-economic \\
\hline Haider, 2020 [65] & $\begin{array}{l}\text { Suggestion to enforce regulations on companies to invest in measures for } \\
\text { risk mitigation of and preparedness to infectious diseases }\end{array}$ & legal \\
\hline $\begin{array}{l}\text { Halabowski \& Rzymski, } \\
2021[54]\end{array}$ & $\begin{array}{l}\text { Recommendation for screening for SARS-CoV-2 and other viruses in } \\
\text { mink but also farm workers; culling of mink as response to SARS-CoV-2 } \\
\text { infections in Denmark, the Netherlands and Spain to prevent spread to } \\
\text { humans; development of vaccine to SARS-CoV-2 for mink }\end{array}$ & $\begin{array}{l}\text { mainly legal; } \\
\text { business/private }\end{array}$ \\
\hline He et al., 2021 [55] & $\begin{array}{c}\text { Quarantining and safely disposing of livestock with suspected } \\
\text { SARS-CoV-2 infection and monitoring novel SARS-CoV-2 strains as } \\
\text { recommended measures }\end{array}$ & mainly legal \\
\hline Hedman et al., 2020 [63] & $\begin{array}{l}\text { Call for improved stewardship of antibiotics by all countries in the } \\
\text { context of poultry farming }\end{array}$ & mainly legal \\
\hline
\end{tabular}


Table A1. Cont.

Reference

\section{Relevant Content}

Main Actors for Implementation, Type of Regulation

Dutch mink farms without SARS-CoV-2 infection are allowed to continue

business under condition of ongoing surveillance activities; culling of mink in Dutch and Danish farms in 2020 because of SARS-CoV-2 infections

legal
Hobbs \& Reid, 2020 [56]

Jones, $2021[61]$

Lindhout \& Reniers, 2020 [49]

OMP, 2020 [64]

Recommendation to improve management of industrial agriculture to impede disease outbreaks and antimicrobial resistance workers, routine disease control and preventive vaccination in farmed animals, rapid isolation of farms once a zoonosis case is detected) mainly legal

Proposed set of measures for improved biosecurity (biosafety education, hygiene measures, distancing from animals, personal protection for farm mainly legal

\begin{tabular}{|c|c|c|}
\hline OMP, 2020 [64] & $\begin{array}{l}\text { Recommendation to improve management of industrial agriculture to } \\
\text { impede disease outbreaks and antimicrobial resistance }\end{array}$ & mainly legal \\
\hline $\begin{array}{l}\text { Open Cages et al., } 2020 \\
{[59]^{2}}\end{array}$ & $\begin{array}{l}\text { Call to limit stocking densities and breed growth rates for poultry in the } \\
\text { UK }\end{array}$ & legal \\
\hline Passi, 2020 [84] & $\begin{array}{l}\text { Monitoring infectious disease emergence in livestock e.g., with GLEWS } \\
\text { as recommendation for a short-term response to zoonotic risk }\end{array}$ & $\begin{array}{l}\text { intergovernmental/supra- } \\
\text { national }\end{array}$ \\
\hline Peters, 2020 [57] & $\begin{array}{l}\text { Massive culling of mink in Dutch and Danish farms in } 2020 \text { because of } \\
\text { SARS-CoV-2 infections }\end{array}$ & legal \\
\hline Pueyo, 2020 [62] & $\begin{array}{l}\text { Suggestion to replace the use of antimicrobials by healthier living } \\
\text { conditions of farm animals }\end{array}$ & mainly legal \\
\hline Sahu et al., 2020 [52] & $\begin{array}{c}\text { Advise for adoption of biosecurity measures such as quarantine on farms, } \\
\text { hygiene in accredited slaughterhouses, safe disposal of effluents from } \\
\text { farms, rearing of native breeds on pastures instead of intensive farming, } \\
\text { prohibition of antibiotic overuse }\end{array}$ & mainly legal \\
\hline $\begin{array}{l}\text { Sikkema \& Koopmans, } \\
2021[87]^{2}\end{array}$ & $\begin{array}{l}\text { Suggestion to use big data analysis, bioinformatics and metagenomics for } \\
\text { rapid detection of pathogens and as tools to identify hot spots of disease } \\
\text { emergence as part of an interdisciplinary One Health approach }\end{array}$ & $\begin{array}{l}\text { mainly } \\
\text { intergovernmental/supra- } \\
\text { national }\end{array}$ \\
\hline $\begin{array}{l}\text { Van Langevelde et al., } \\
\qquad 2020[51]\end{array}$ & $\begin{array}{l}\text { Suggested policy to reduce probability of contact between wildlife and } \\
\text { livestock and to ensure good sanitary conditions and sanitary controls to } \\
\text { safeguard health of livestock animals }\end{array}$ & mainly legal \\
\hline Xia et al., $2020[58]^{1}$ & $\begin{array}{c}\text { Massive culling of mink in Danish farms in } 2020 \text { because of SARS-CoV-2 } \\
\text { infections }\end{array}$ & legal \\
\hline \multicolumn{3}{|c|}{ Dietary changes } \\
\hline $\begin{array}{l}\text { Attwood \& Hajat, } 2020 \\
{[97]}\end{array}$ & $\begin{array}{l}\text { Increased demand of organic products in high-income countries during } \\
\text { spring } 2020 \text { partly based on consumers' food safety concerns }\end{array}$ & consumers \\
\hline $\begin{array}{l}\text { Bogueva \& Marinova, } \\
\quad 2020[74]\end{array}$ & $\begin{array}{l}\text { Proposal for sustainability social marketing to encourage curbing } \\
\text { consumption of animal products, accompanying taxation of } \\
\text { animal-based foods }\end{array}$ & $\begin{array}{l}\text { governmental- } \\
\text { informational }\end{array}$ \\
\hline Daszak et al., 2020 [75] & Call to reduce excessive meat consumption from livestock production & consumers \\
\hline Dhont et al., 2021 [101] & $\begin{array}{l}\text { UK survey: zoonotic risk by factory farming and global meat } \\
\text { consumption rated less important by consumers than wildlife trade and } \\
\text { consumption, even when scientific information was provided on their } \\
\text { equal importance; this effect was particularly pronounced in those eating } \\
\text { high meat diets }\end{array}$ & consumers \\
\hline Espinosa et al., 2020 [34] & $\begin{array}{l}\text { Recommendation for informational policies to restrict meat consumption } \\
\text { and to promote plant-based diets and for reviewing role of plant-based } \\
\text { diets in nutritional guidelines }\end{array}$ & $\begin{array}{l}\text { governmental- } \\
\text { informational }\end{array}$ \\
\hline
\end{tabular}


Table A1. Cont.

\begin{tabular}{|c|c|c|}
\hline Reference & Relevant Content & $\begin{array}{l}\text { Main Actors for } \\
\text { Implementation, Type } \\
\text { of Regulation }\end{array}$ \\
\hline FAO, $2020[96]^{1}$ & $\begin{array}{l}\text { Decline of worldwide meat consumption in 2020, mainly due to supply } \\
\text { chain disruptions and economic hardships because of COVID-19 }\end{array}$ & consumers \\
\hline Ghislain, 2021 [82] ${ }^{2}$ & $\begin{array}{l}\text { Suggestion of introducing an EU-wide mandatory label on animal } \\
\text { products stating the production method }\end{array}$ & $\begin{array}{l}\text { governmental- } \\
\text { informational }\end{array}$ \\
\hline Greger, 2020 [66] & $\begin{array}{l}\text { Call for reduction of meat consumption which also addresses the climate } \\
\text { crisis and health issues }\end{array}$ & consumers \\
\hline $\begin{array}{l}\text { Halabowski \& Rzymski, } \\
2021 \text { [54] }\end{array}$ & $\begin{array}{c}\text { Decrease of global meat consumption during COVID-19 for different } \\
\text { reasons }\end{array}$ & consumers \\
\hline Jones, $2021[61]$ & $\begin{array}{l}\text { Suggestion of a moral obligation on the part of consumers not to buy and } \\
\text { eat meat whose production is associated with zoonotic risk }\end{array}$ & consumers \\
\hline Niemiec et al., 2021 [102] ${ }^{2}$ & $\begin{array}{l}\text { U.S. survey: message about pandemic risk by factory farming did not } \\
\text { cause stronger intentions to reduce meat consumption and try } \\
\text { plant-based meat alternatives than messages about benefits for health, } \\
\text { animal welfare, and the environment }\end{array}$ & consumers \\
\hline Pueyo, 2020 [62] & $\begin{array}{l}\text { Information campaigns emphasising benefits of dietary change including } \\
\text { advice how to carry it out could be funded by tax on factory farming }\end{array}$ & $\begin{array}{l}\text { governmental- } \\
\text { informational }\end{array}$ \\
\hline \multirow[t]{2}{*}{ Schockmel, 2020 [99] } & Examples of how COVID-19 has stimulated adoption of a vegan diet & consumers \\
\hline & Alternatives to animal products & \\
\hline Anomaly, $2020[78]^{1}$ & $\begin{array}{l}\text { Proposal to urge governments to invest in development and mass } \\
\text { production of cell-based meat }\end{array}$ & governmental-economic \\
\hline $\begin{array}{l}\text { Attwood \& Hajat, } 2020 \\
\qquad[97]\end{array}$ & $\begin{array}{l}\text { Increased sales of plant-based meat alternatives in the US during spring } \\
2020 \text { partly based on consumers' food safety concerns }\end{array}$ & consumers \\
\hline $\begin{array}{l}\text { Broom, } 2020[48] ; \text { Petrovan } \\
\quad \text { et al., } 2020 \text { [47] }^{1}\end{array}$ & $\begin{array}{l}\text { Suggest promotion of substitutes for animal products by governments } \\
\text { "and others", including synthetic or plant-based products (e.g., cultured } \\
\text { meat, synthetic fur) }\end{array}$ & $\begin{array}{l}\text { mainly governmental- } \\
\text { informational }\end{array}$ \\
\hline $\begin{array}{l}\text { Bryant \& Sanctorum, } 2021 \\
\qquad[103]^{2}\end{array}$ & $\begin{array}{c}\text { Survey in Belgium: no change of consumers' attitudes towards } \\
\text { plant-based and cultured meat after the first coronavirus wave; } \\
\text { satisfaction with plant-based meat alternatives slightly but significantly } \\
\text { increased }\end{array}$ & consumers \\
\hline Espinosa et al., 2020 [34] & $\begin{array}{l}\text { Recommend subsidising development of insect-based food and cultured } \\
\text { meat }\end{array}$ & governmental-economic \\
\hline $\begin{array}{l}\text { Halabowski \& Rzymski, } \\
\qquad 2021[54]\end{array}$ & $\begin{array}{l}\text { State high importance of research and development regarding alternative } \\
\text { meat, foremost cultured meat }\end{array}$ & $\begin{array}{l}\text { business/private; } \\
\text { governmental-economic }\end{array}$ \\
\hline Lee, 2021 [98] & Heightened consumers' interest in plant-based meat alternatives & consumers \\
\hline Niemiec et al., 2021 [102] ${ }^{2}$ & $\begin{array}{l}\text { U.S. survey: message about pandemic risk by factory farming did not } \\
\text { cause stronger intentions to try plant-based meat alternatives than } \\
\text { messages about benefits for health, animal welfare, and the environment }\end{array}$ & consumers \\
\hline Rzymski et al., 2021 [79] & $\begin{array}{c}\text { Call for funding research and development of cultured meat to overcome } \\
\text { technological obstacles, creating public awareness, and initiate } \\
\text { regulations for market introduction }\end{array}$ & $\begin{array}{l}\text { governmental-economic, } \\
\text { governmental- } \\
\text { informational }\end{array}$ \\
\hline Schuck-Paim, 2020 [73] & $\begin{array}{l}\text { Investments should be directed to development of safe food sources that } \\
\text { are competitive alternatives to conventional animal-based products }\end{array}$ & governmental-economic \\
\hline Smith et al., $2021[80]^{2}$ & $\begin{array}{l}\text { Recommendations (specifically for the US) for public funding of research } \\
\text { and development of plant-based and cultured meat, expanding existing } \\
\text { funding for alternative meats, and targeting promising innovations e.g., } \\
\text { to lower prices and identify cell lines }\end{array}$ & governmental-economic \\
\hline
\end{tabular}


Table A1. Cont.

\begin{tabular}{|c|c|c|}
\hline Reference & Relevant Content & $\begin{array}{c}\text { Main Actors for } \\
\text { Implementation, Type } \\
\text { of Regulation }\end{array}$ \\
\hline $\begin{array}{l}\text { Wiebers \& Feigin, } 2020 \\
\qquad[20]^{1}\end{array}$ & $\begin{array}{l}\text { Advise to rapidly adopt eating protein that is safer for humans, including } \\
\text { plant-based and cultured meat }\end{array}$ & consumers \\
\hline \multicolumn{3}{|c|}{ Prohibition of factory farming } \\
\hline Greger, 2020 [66] & Call for shutting down factory farms & legal \\
\hline $\begin{array}{l}\text { Halabowski \& Rzymski, } \\
2021 \text { [54] }\end{array}$ & Dutch parliament prohibited mink farming by end of 2020 & legal \\
\hline $\begin{array}{l}\text { Hobbs \& Reid, } 2020[56] \\
\text { Denis et al., } 2020[70]^{1}\end{array}$ & Dutch mink farms infected with SARS-CoV-2 closed by law & legal \\
\hline $\begin{array}{l}\text { Open Cages et al., } 2020 \\
{[59]^{2}}\end{array}$ & Request to the UK government to phase out intensive poultry farming & legal \\
\hline $\begin{array}{l}\text { Peters, } 2020[57] ; \text { Xia et al., } \\
2020[58]^{1}\end{array}$ & Prohibition of mink farming by Dutch parliament & legal \\
\hline $\begin{array}{l}\text { Wiebers \& Feigin, } 2020 \\
{[20]^{1}}\end{array}$ & Confining animals in factory farms should be discontinued globally & legal \\
\hline \multicolumn{3}{|c|}{ Taxation on animal products } \\
\hline $\begin{array}{l}\text { Blum \& Neumärker, } 2020 \\
\text { [76] }\end{array}$ & $\begin{array}{l}\text { Taxation on animal products suggested to be useful for promoting } \\
\text { sustainable dietary behaviour }\end{array}$ & governmental-economic \\
\hline $\begin{array}{c}\text { Bogueva \& Marinova, } \\
2020 \text { [74]; Espinosa et al., } \\
2020 \text { [34] }\end{array}$ & $\begin{array}{l}\text { Suggest imposing tax on animal-based products, i.e., a "zoonotic" tax } \\
\text { (Espinosa et al., } 2020 \text { [33]) }\end{array}$ & governmental-economic \\
\hline Daszak et al., 2020 [75] & $\begin{array}{l}\text { Suggest considering taxes or levies on meat consumption where there is } \\
\text { clear evidence for high pandemic risk }\end{array}$ & governmental-economic \\
\hline Jones, $2021[61]$ & $\begin{array}{l}\text { For short-term zoonotic risk mitigation, higher taxes could be imposed } \\
\text { on meat produced by risky practices such as from CAFOs }\end{array}$ & governmental-economic \\
\hline \multicolumn{3}{|c|}{ Economic regulation of factory farming } \\
\hline Daszak et al., 2020 [75] & $\begin{array}{l}\text { Suggest considering taxes or levies on meat or livestock production } \\
\text { where there is clear evidence for high pandemic risk }\end{array}$ & governmental-economic \\
\hline Espinosa et al., 2020 [34] & $\begin{array}{l}\text { Proposal to subsidise farms according to the zoonotic risk of their } \\
\text { activities }\end{array}$ & governmental-economic \\
\hline Haider, 2020 [65] & $\begin{array}{l}\text { Suggestion to enforce regulations on companies to invest in measures for } \\
\text { risk mitigation of and preparedness to infectious diseases }\end{array}$ & legal \\
\hline $\begin{array}{l}\text { Open Cages et al., } 2020 \\
{[59]^{2}}\end{array}$ & $\begin{array}{l}\text { Call for UK food retailers and supermarkets to quit marketing of chicken } \\
\text { from intensive farming }\end{array}$ & business/private \\
\hline Pueyo, 2020 [62] & Taxes on industrial animal farming to be considered & governmental-economic \\
\hline Schuck-Paim, 2020 [73] & $\begin{array}{l}\text { Divestment from companies involved in factory farming and avoidance } \\
\text { of investing in such companies as critical contributions }\end{array}$ & business/private \\
\hline \multicolumn{3}{|c|}{ Support for sustainable farming } \\
\hline Ghislain, $2021[82]^{2}$ & $\begin{array}{l}\text { Suggestion of introducing an EU-wide mandatory label on animal } \\
\text { products stating the production method }\end{array}$ & $\begin{array}{l}\text { governmental- } \\
\text { informational }\end{array}$ \\
\hline Lee, $2021[98]$ & $\begin{array}{l}\text { Reports on increasing consumers' interest in products from organic } \\
\text { farming }\end{array}$ & consumers \\
\hline Lurie, 2020 [90] & $\begin{array}{c}\text { Private investments are advocated to be directed to food systems that } \\
\text { exhibit sustainable farming practices }\end{array}$ & business/private \\
\hline
\end{tabular}


Table A1. Cont.

\begin{tabular}{|c|c|c|}
\hline Reference & Relevant Content & $\begin{array}{l}\text { Main Actors for } \\
\text { Implementation, Type } \\
\text { of Regulation }\end{array}$ \\
\hline Lymbery, 2020 [17] 2 & $\begin{array}{l}\text { Call for urgent action to move away from factory farming practices } \\
\text { globally in favour of an agro-ecological food system }\end{array}$ & no preferred policy \\
\hline $\begin{array}{l}\text { Montenegro de Wit, } 2021 \\
\text { [77] }\end{array}$ & $\begin{array}{l}\text { Agro-ecological practices presented as alternative to factory farms, } \\
\text { contributing to pandemic control }\end{array}$ & $\begin{array}{l}\text { mainly } \\
\text { governmental-economic }\end{array}$ \\
\hline $\begin{array}{l}\text { Open Cages et al., } 2020 \\
\qquad[59]^{2}\end{array}$ & $\begin{array}{c}\text { In the long term, chicken sold in UK supermarkets should be from } \\
\text { organic agriculture only }\end{array}$ & business/private, legal \\
\hline Pueyo, 2020 [62] & $\begin{array}{l}\text { Tax on factory farming to be used to effectuate transition to alternative, } \\
\text { sustainable agri-food schemes }\end{array}$ & governmental-economic \\
\hline $\begin{array}{l}\text { Wiebers \& Feigin, } 2020 \\
\qquad[20]^{1}\end{array}$ & $\begin{array}{l}\text { Additional funding of plant-based agriculture to promote growing food } \\
\text { for humans rather than feed for livestock to feed humans }\end{array}$ & governmental-economic \\
\hline \multicolumn{3}{|c|}{ One Health approach } \\
\hline Ellwanger et al., 2021 [50] & Reduction of human contact with livestock as part of One Health & $\begin{array}{l}\text { intergovernmental/supra- } \\
\text { national, } \\
\text { legal }\end{array}$ \\
\hline Daszak et al., 2020 [75] & $\begin{array}{l}\text { Suggest formation of an intergovernmental council to identify and alert } \\
\text { to pandemic risk, and to inform intervention and control measures; } \\
\text { suggestion for institutionalisation of the One Health approach by } \\
\text { national governments }\end{array}$ & $\begin{array}{l}\text { intergovernmental/supra- } \\
\text { national; } \\
\text { legal }\end{array}$ \\
\hline Passi, 2020 [84] & $\begin{array}{l}\text { One Health as long-term solution to reduce risk of further zoonotic } \\
\text { outbreaks }\end{array}$ & $\begin{array}{l}\text { intergovernmental/supra- } \\
\text { national }\end{array}$ \\
\hline Peters, 2020 [57] & $\begin{array}{c}\text { Claims a pronounced scope of the One Health concept also on livestock; } \\
\text { suggestion to modify and strengthen One Health to become a legal } \\
\text { principle, call for global animal law }\end{array}$ & $\begin{array}{l}\text { intergovernmental/supra- } \\
\text { national, } \\
\text { legal }\end{array}$ \\
\hline $\begin{array}{l}\text { Sikkema \& Koopmans, } \\
2021[87]^{2}\end{array}$ & $\begin{array}{l}\text { Suggestion to use big data analysis, bioinformatics, and metagenomics } \\
\text { for rapid detection of pathogens and as tools to identify hot spots of } \\
\text { disease emergence as part of an interdisciplinary One Health approach }\end{array}$ & $\begin{array}{l}\text { mainly } \\
\text { intergovernmental/supra- } \\
\text { national }\end{array}$ \\
\hline ten Have, 2020 [88] & $\begin{array}{l}\text { Health governance should be global as represented by the One Health } \\
\text { principle which implies surveillance of human connections with animals } \\
\text { particularly in the bioindustry }\end{array}$ & $\begin{array}{l}\text { intergovernmental/supra- } \\
\text { national }\end{array}$ \\
\hline \multicolumn{3}{|c|}{ Ban on wildlife trade } \\
\hline $\begin{array}{l}\text { Booth et al., } 2021[72] \\
\quad \text { OMP, } 2020[64]\end{array}$ & $\begin{array}{l}\text { Meat from livestock production would have to replace wildlife meat if } \\
\text { banned, driving land-use change and ensuing zoonotic infectious disease } \\
\text { risk }\end{array}$ & legal \\
\hline Roe et al., 2020 [19] & $\begin{array}{l}\text { Habitat destruction and industrial livestock production as key drivers of } \\
\text { zoonotic risk are unintended consequences of replacing wildlife with } \\
\text { livestock meat }\end{array}$ & legal \\
\hline Roe \& Lee, 2021 [71] & $\begin{array}{l}\text { Ban on wild meat consumption could entail more consumption of meat } \\
\text { from livestock, leading to habitat destruction (due to growing plants for } \\
\text { animal feed) and intensification of livestock production, key drivers of } \\
\text { zoonotic risk }\end{array}$ & legal \\
\hline
\end{tabular}

Dense human populations favour encounter and spread of zoonotic pathogens; to feed more people, more factory farms are needed that

Rubenstein, 2020 [81] increase zoonotic risk even more. The author suggests reduction of U.S. governmental-economic population to 150 mio inhabitants by tax incentives to limit maximum number of offspring

\footnotetext{
${ }^{1}$ Relevant literature located from the references, part of the core literature. ${ }^{2}$ Relevant literature identified from additional searches on each topic, not part of the core literature.
} 


\section{References}

1. Huang, C.; Wang, Y.; Li, X.; Ren, L.; Zhao, J.; Hu, Y.; Zhang, L.; Fan, G.; Xu, J.; Gu, X.; et al. Clinical features of patients infected with 2019 novel coronavirus in Wuhan, China. Lancet 2020, 395, 497-506. [CrossRef]

2. Wang, C.; Horby, P.W.; Hayden, F.G.; Gao, G.F. A novel coronavirus outbreak of global health concern. Lancet 2020, 395, 470-473. [CrossRef]

3. Shereen, M.A.; Khan, S.; Kazmi, A.; Bashir, N.; Siddique, R. COVID-19 infection: Emergence, transmission, and characteristics of human coronaviruses. J. Adv. Res. 2020, 24, 91-98. [CrossRef]

4. do Vale, B.; Lopes, A.P.; da Conceição Fontes, M.; Silvestre, M.; Cardoso, L.; Coelho, A.C. Bats, pangolins, minks and other animals—villains or victims of SARS-CoV-2? Vet. Res. Commun. 2021, 45, 1-19. [CrossRef]

5. Li, Q.; Guan, X.; Wu, P.; Wang, X.; Zhou, L.; Tong, Y.; Ren, R.; Leung, K.S.; Lau, E.H.; Wong, J.Y.; et al. Early transmission dynamics in Wuhan, China, of novel coronavirus-infected pneumonia. N. Engl. J. Med. 2020, 382, 1199-1207. [CrossRef]

6. WHO: Zoonoses. Available online: https://www.who.int/news-room/fact-sheets/detail/zoonoses (accessed on 7 March 2021).

7. Woolhouse, M.E.J.; Gowtage-Sequeria, S. Host range and emerging and reemerging pathogens. Emerg. Infect. Dis. 2005, 11, 1842-1847. [CrossRef]

8. Jones, K.E.; Patel, N.G.; Levy, M.A.; Storeygard, A.; Balk, D.; Gittleman, J.L.; Daszak, P. Global trends in emerging infectious diseases. Nature 2008, 451, 990-993. [CrossRef] [PubMed]

9. Watkins, K. Emerging Infectious Diseases: A review. Curr. Emerg. Hosp. Med. Rep. 2018, 6, 86-93. [CrossRef] [PubMed]

10. Sohail, M. Elements of a flu pandemic. J. Mol. Genet. Med. 2005, 1, 38-39. [CrossRef] [PubMed]

11. Morens, D.M.; Folkers, G.K.; Fauci, A.S. The challenge of emerging and re-emerging infectious diseases. Nature 2004, 430, $242-249$. [CrossRef]

12. Morens, D.M.; Fauci, A.S. Emerging Infectious Diseases in 2012: 20 years after the Institute of Medicine report. $m$ Bio 2012, 3 , e00494-12. [CrossRef] [PubMed]

13. Everard, M.; Johnston, P.; Santillo, D.; Staddon, C. The role of ecosystems in mitigation and management of COVID-19 and other zoonoses. Environ. Sci. Policy 2020, 111, 7-17. [CrossRef] [PubMed]

14. Diamond, J. Guns, Germs, and Steel: The Fates of Human Societies, 1st ed.; W.W. Norton \& Co.: New York, NY, USA, $1997 ;$ p. 480.

15. Bell, D.; Roberton, S.; Hunter, P.R. Animal origins of SARS coronavirus: Possible links with the international trade in small carnivores. Phil. Trans. R. Soc. Lond. B 2004, 359, 1107-1114. [CrossRef] [PubMed]

16. Gibbs, A.J.; Armstrong, J.S.; Downie, J.C. From where did the 2009 “swine-origin" influenza A virus (HINI) emerge? Virol. J. 2009, 6, 207. [CrossRef] [PubMed]

17. Lymbery, P. COVID-19: How industrial animal agriculture fuels pandemics. Derecho Anim. Forum Anim. Law Stud. 2020, 11, 141-149. [CrossRef]

18. Jones, B.A.; Grace, D.; Kock, R.; Alonso, S.; Rushton, J.; Said, M.; McKeever, D.; Mutua, F.; Young, J.; McDermott, J.; et al. Zoonosis emergence linked to agricultural intensification and environmental change. Proc. Natl. Acad. Sci. USA 2013, 110, 8399-8404. [CrossRef]

19. Roe, D.; Dickman, A.; Kock, R.; Milner-Gulland, E.J.; Rihoy, E. Beyond banning wildlife trade: COVID-19, conservation and development. World Dev. 2020, 136, 105121. [CrossRef]

20. Wiebers, D.O.; Feigin, V.L. What the COVID-19 crisis is telling humanity. Neuroepidemiology 2020, 54, 283-286. [CrossRef]

21. Shortridge, K.F.; Peiris, J.S.M.; Guan, Y. The next influenza pandemic: Lessons from Hong Kong. J. Appl. Microbiol. 2003, 94, 70S-79S. [CrossRef] [PubMed]

22. Epstein, J.H.; Field, H.E.; Luby, S.; Pulliam, J.R.C.; Daszak, P. Nipah virus: Impact, origins, and causes of emergence. Curr. Infect. Dis. Rep. 2006, 8, 59-65. [CrossRef] [PubMed]

23. Graham, J.P.; Leibler, J.; Price, L.B.; Otte, J.M.; Pfeiffer, D.; Tiensin, T.; Silbergeld, E.K. The animal-human interface and infectious disease in industrial food animal production: Rethinking biosecurity and biocontainment. Public Health Rep. 2008, 123, 282-299. [CrossRef]

24. Moekti, G.R. Industrial livestock production: A review on advantages and disadvantages. IOP Conf. Ser. Earth Environ. Sci. 2020, 492, 012094. [CrossRef]

25. Ilea, R.C. Intensive livestock farming: Global trends, increased environmental concerns, and ethical solutions. J. Agric. Environ. Ethics 2009, 22, 153-167. [CrossRef]

26. Anomaly, J. What's wrong with factory farming? Public Health Ethics 2015, 8, 246-254. [CrossRef]

27. Ma, W.; Lager, K.M.; Vincent, A.L.; Janke, B.H.; Gramer, M.R.; Richt, J.A. The role of swine in the generation of novel influenza viruses. Zoonoses Public Health 2009, 56, 326-337. [CrossRef]

28. Schmidt, C.W. Swine CAFOs \& novel H1N1 flu: Separating facts from fears. Environ. Health Perspect. 2009, $117,394-401$. [CrossRef]

29. de Haan, C.; Schillhorn van Veen, T.; Brandenburg, B.; Gauthier, J.; Le Gall, F.; Mearns, R.; Siméon, M. Livestock Development: Implications for Rural Poverty, the Environment, and Global Food Security; The World Bank: Washington, DC, USA, 2001. Available online: https: / / EconPapers.repec.org/RePEc:wbk:wbpubs:14006 (accessed on 25 March 2021).

30. Anomaly, J. Intensive Animal Agriculture and Human Health. In The Routledge Handbook of Animal Ethics; Fischer, B., Ed.; Routledge, Taylor \& Francis: London, UK, 2020; pp. 167-176. Available online: https://philarchive.org/archive/ANOIAA (accessed on 25 March 2021). 
31. Holmes, A.H.; Moore, L.S.P.; Sundsfjord, A.; Steinbakk, M.; Regmi, S.; Karkey, A.; Guerin, P.; Piddock, L. Understanding the mechanisms and drivers of antimicrobial resistance. Lancet 2016, 387, 176-187. [CrossRef]

32. Stoll-Kleemann, S.; Schmidt, U.J. Reducing meat consumption in developed and transition countries to counter climate change and biodiversity loss: A review of influence factors. Reg. Environ. Chang. 2017, 17, 1261-1277. [CrossRef]

33. Leibler, J.H.; Otte, J.; Roland-Holst, D.; Pfeiffer, D.U.; Magalhaes, R.S.; Rushton, J.; Graham, J.P.; Silbergeld, E.K. Industrial food animal production and global health risks: Exploring the ecosystems and economics of avian influenza. EcoHealth 2009, 6, 58-70. [CrossRef] [PubMed]

34. Espinosa, R.; Tago, D.; Treich, N. Infectious diseases and meat production. Environ. Resour. Econ. 2020, 76, 1019-1044. [CrossRef] [PubMed]

35. Robbins, J.A. Be wary of simple solutions to complex problems. Anim. Sentience 2020, 30, 16. [CrossRef]

36. Wiebers, D.O.; Feigin, V.L. Heeding the call of COVID-19. Anim. Sentience 2021, 30, 30. [CrossRef]

37. FAOSTAT: Food Supply—Livestock and Fish Primary Equivalent. Available online: http://www.fao.org/faostat/en/\#data/CL/ visualize (accessed on 28 March 2021).

38. Godfray, H.C.J.; Aveyard, P.; Garnett, T.; Hall, J.W.; Key, T.J.; Lorimer, J.; Pierrehumbert, R.T.; Scarborough, P.; Springmann, M.; Jebb, S.A. Meat consumption, health, and the environment. Science 2018, 361, eaam5324. [CrossRef] [PubMed]

39. Xie, X.; Huang, L.; Li, J.; Zhu, H. Generational differences in perceptions of food health/risk and attitudes toward organic food and game meat: The case of the COVID-19 crisis in China. Int. J. Environ. Res. Public Health 2020, 17, 3148. [CrossRef]

40. Severo, E.A.; Ferro de Guimarães, J.C.; Dellarmelin, M.L. Impact of the COVID-19 pandemic on environmental awareness, sustainable consumption and social responsibility: Evidence from generations in Brazil and Portugal. J. Clean. Prod. 2021, 286, 124947. [CrossRef] [PubMed]

41. Koh, L.P.; Li, Y.; Lee, J.S.H. The value of China's ban on wildlife trade and consumption. Nat. Sustain. 2021, 4, 2-4. [CrossRef]

42. Chakraborty, I.; Maity, P. COVID-19 outbreak: Migration, effects on society, global environment and prevention. Sci. Total Environ. 2020, 728, 138882. [CrossRef] [PubMed]

43. Yang, N.; Liu, P.; Li, W.; Zhang, L. Permanently ban wildlife consumption. Science 2020, 367, 1434-1435. [CrossRef]

44. Arksey, H.; O’Malley, L. Scoping studies: Towards a methodological framework. Int. J. Soc. Res. Methodol. 2005, 8, 19-32. [CrossRef]

45. Levac, D.; Colquhoun, H.; O’Brien, K.K. Scoping studies: Advancing the methodology. Implement. Sci. 2010, 5, 69. [CrossRef]

46. Steurer, R. Disentangling governance: A synoptic view of regulation by government, business and civil society. Policy Sci. 2013, 46, 387-410. [CrossRef]

47. Petrovan, S.O.; Aldridge, D.C.; Bartlett, H.; Bladon, A.J.; Booth, H.; Broad, S.; Broom, D.M.; Burgess, N.D.; Cleaveland, S.; Cunningham, A.A.; et al. Post COVID-19: A solution scan of options for preventing future zoonotic epidemics. OSF 2020. [CrossRef]

48. Broom, D.A. The necessity of human attitude change and methods of avoiding pandemics. Anim. Sentience 2020, 30, 7. [CrossRef]

49. Lindhout, P.; Reniers, G. Reflecting on the safety zoo: Developing an integrated pandemics barrier model using early lessons from the COVID-19 pandemic. Saf. Sci. 2020, 130, 104907. [CrossRef] [PubMed]

50. Ellwanger, J.H.; Gorini da Veiga, A.B.; de Lima Kaminski, V.; Valverde-Villegas, J.M.; Quintino de Freitas, A.W.; Bogo Chies, J.A. Control and prevention of infectious diseases from a One Health perspective. Genet. Mol. Biol. 2021, 44 (Suppl. 1), e20200256. [CrossRef]

51. van Langevelde, F.; Rivera Mendoza, H.R.; Matson, K.D.; Esser, H.J.; de Boer, W.F.; Schindler, S. The Link between Biodiversity Loss and the Increasing Spread of Zoonotic Diseases; Policy Department for Economic, Scientific and Quality of Life Policies, European Parliament: Luxembourg, 2020. Available online: https:/ /www.europarl.europa.eu/RegData/etudes/IDAN/2020/658217/ IPOL_IDA(2020)658217_EN.pdf (accessed on 25 April 2021).

52. Sahu, R.; Das, D.P.; Nayak, S. Emergence of zoonoses at human-animal interface. Int. J. Curr. Microbiol. Appl. Sci. 2021, 9 , 2894-2905. [CrossRef]

53. Aigner, K.; Bruckner, S.; Durmaz, A.; Eder, F.; Feichtlbauer, P.; Geyer, A.; Hohenberger, F.; Lienbacher, S.; Michael, S.; Mutoro, N.; et al. The COVID-19 Pandemic Has Clear Links to Nature Exploitation and Destruction; Department of Biosciences, University of Salzburg: Salzburg, Austria, 2020. Available online: https://www.plus.ac.at/wp-content/uploads/2021/02/1_COVID_Essay_ whole_group_FINAL_JP_AT_FINALLLL.pdf (accessed on 25 April 2021).

54. Halabowski, D.; Rzymski, P. Taking a lesson from the COVID-19 pandemic: Preventing the future outbreaks of viral zoonoses through a multi-faceted approach. Sci. Total Environ. 2021, 757, 143723. [CrossRef] [PubMed]

55. He, S.; Han, J.; Lichtfouse, E. Backward transmission of COVID-19 from humans to animals may propagate reinfections and induce vaccine failure. Environ. Chem. Lett. 2021, 19, 763-768. [CrossRef]

56. Hobbs, E.C.; Reid, T.J. Animals and SARS-CoV-2: Species susceptibility and viral transmission in experimental and natural conditions, and the potential implications for community transmission. Transbound. Emerg. Dis. 2021, 68, 1850-1867. [CrossRef]

57. Peters, A. COVID-19 shows the need for a global animal law. Derecho Anim. Forum Anim. Law Stud. 2020, 11, 86-97. [CrossRef]

58. Xia, C.; Lam, S.S.; Sonne, C. Ban unsustainable mink production. Science 2020, 370, 539. [CrossRef]

59. Open Cages; Knight, A; Wiebers, D. A British Pandemic: The Cruelty and Danger of Supermarket Chicken; Open Cages: London, UK, 2020. Available online: https://www.afisapr.org.br/attachments/article/2020/A\%20British\%20Pandemic_\%20The\%20 Cruelty\%20and\%20Danger\%20of\%20Supermarket\%20Chicken.pdf (accessed on 23 May 2021). 
60. Andrews, C. Factory farming time to change? [Coronavirus Farming]. Eng. Technol. 2020, 15, 48-51. [CrossRef]

61. Jones, B. Eating meat and not vaccinating: In defense of the analogy. Bioethics 2021, 35, 135-142. [CrossRef] [PubMed]

62. Pueyo, S. Jevon's paradox and a tax on aviation to prevent the next pandemic. SocArXiv 2020. [CrossRef]

63. Hedman, H.D.; Vasco, K.A.; Zhang, L. A review of antimicrobial resistance in poultry farming within low-resource settings. Animals 2020, 10, 1264. [CrossRef] [PubMed]

64. Oxford Martin Programme (OMP) on the Illegal Wildlife Trade and Interdisciplinary Centre for Conservation Science. Position Statement: Managing Wildlife Trade in the Context of COVID-19 and Future Zoonotic Pandemics; University of Oxford: Oxford, UK, 2020. [CrossRef]

65. Haider, H. Mitigating the economic impacts of epidemics and financial crises: Focus on middle-income countries. In K4D Helpdesk Report 812; Institute of Development Studies: Brighton, UK, 2020. Available online: https://opendocs.ids.ac.uk/opendocs/ bitstream/handle/20.500.12413/15306/812_mitigating_the_economic_impacts_of_epidemics_financial_crises.pdf?sequence= 6\&isAllowed=y (accessed on 8 May 2021).

66. Greger, M. Whenever possible, treat the cause: Shut down the flu factories. Anim. Sentience 2020, 30, 4. [CrossRef]

67. Zhou, P.; Shi, Z.-L. SARS-CoV-2 spillover events. Science 2021, 371, 120-122. [CrossRef]

68. Oude Munnink, B.B.; Sikkema, R.S.; Nieuwenhuijse, D.F.; Molenaar, R.J.; Munger, E.; Molenkamp, R.; Spek, A.; van der Tolsma, P.; Rietveld, A.; Brouwer, M.; et al. Transmission of SARS-CoV-2 on mink farms between humans and mink and back to humans. Science 2021, 371, 172-177. [CrossRef] [PubMed]

69. WHO: SARS-CoV-2 Mink-Associated Variant Strain-Denmark. Available online: https://www.who.int/csr/don/06-november2020-mink-associated-sars-cov2-denmark/en/ (accessed on 1 May 2021).

70. Denis, M.; Vandeweerd, V.; Verbeeke, R.; Laudisoit, A.; Reid, T.; Hobbs, E.; Wynants, L.; Van der Vliet, D. COVIPENDIUM: Information available to support the development of medical countermeasures and interventions against COVID-19 (version Oct. 7th, 2020). Transdiscipl. Insights 2020, 4, 1-296. [CrossRef]

71. Roe, D.; Lee, T.M. Possible negative consequences of a wildlife trade ban. Nat. Sustain. 2021, 4, 5-6. [CrossRef]

72. Booth, H.; Clark, M.; Milner-Gulland, E.; Amponsah-Mensah, K.; Antunes, A.P.; Brittain, S.; Castilho, L.C.; Campos-Silva, J.V.; Constantino, P.D.A.L.; Li, Y.; et al. Investigating the risks of removing wild meat from global food systems. Curr. Biol. 2021, 31, 1-10. [CrossRef]

73. Schuck-Paim, C. Intensive animal farming conditions are a major threat to global health. Anim. Sentience 2020, 30, 8. [CrossRef]

74. Bogueva, D.; Marinova, D. Influencing dietary changes in a zoonotic disease crisis. Mov. Nutr. Health Dis. 2020, 4, 70-72. [CrossRef]

75. Daszak, P.; Amuasi, J.; das Neves, C.G.; Hayman, D.; Kuiken, T.; Roche, B.; Zambrana-Torrelio, C.; Buss, P.; Dundarova, H.; Feferholtz, Y.; et al. Workshop Report on Biodiversity and Pandemics of the Intergovernmental Platform on Biodiversity and Ecosystem Services (IPBES); IPBES Secretariat: Bonn, Germany, 2020. [CrossRef]

76. Blum, B.; Neumärker, B. Globalization, Environmental Damage and the Corona Pandemic-Lessons from the Crisis for Economic, Environmental and Social Policy. SSRN 2020. [CrossRef]

77. Montenegro de Wit, M. What grows from a pandemic? Toward an abolitionist agroecology. J. Peasant Stud. 2021, 48, 99-136. [CrossRef]

78. Anomaly, J. Cultured meat would prevent the next COVID crisis. Anim. Sentience 2020, 30, 5. [CrossRef]

79. Rzymski, P.; Kulus, M.; Jankowski, M.; Dompe, C.; Bryl, R.; Petitte, J.N.; Kempisty, B.; Mozdziak, P. COVID-19 pandemic is a call to search for alternative protein sources as food and feed: A review of possibilities. Nutrients 2021, 13, 150. [CrossRef]

80. Smith, A.; Shah, S.; Blaustein-Rejto, D. The Case for Public Investment in Alternative Proteins; The Breakthrough Institute: Oakland, CA, USA, 2021. Available online: https://s3.us-east-2.amazonaws.com/uploads.thebreakthrough.org/Alternative-ProteinReport_v6.pdf (accessed on 18 May 2021).

81. Rubenstein, E.S. Coronavirus and Human Population Growth; NPG Forum Paper; Negative Population Growth, Inc.: Alexandria, VA, USA, 2020. Available online: https://npg.org/wp-content/uploads/2020/06/CoronavirusAndHumanPopulationGrowthFP2020.pdf (accessed on 9 May 2021).

82. Ghislain, S. Mandatory method-of-production labelling for animal products in the EU: A case study. Glob. Trade Cust. J. 2021, 16, 158-169. Available online: https://kluwerlawonline.com/JournalArticle/Global+Trade+and+Customs+Journal/16.4/GTCJ2 021017 (accessed on 17 May 2021).

83. Mackenzie, J.S.; Jeggo, M. The One Health approach—Why is it so important? Trop. Med. Infect. Dis. 2019, 4, 88. [CrossRef]

84. Passi, G.R. Origin of pandemics. Indian J. Pract. Pediatr. 2020, 22, 117-120. Available online: https://www.ijpp.in/Files/2020 /ver2/Origin-of-Pandemics.pdf (accessed on 25 April 2021).

85. WHO: Global Early Warning System for Major Animal Diseases, including Zoonoses (GLEWS). Available online: https://www. who.int/zoonoses/outbreaks/glews/en/ (accessed on 24 April 2021).

86. Carroll, D.; Morzaria, S.; Briand, S.; Johnson, C.K.; Morens, D.; Sumption, K.; Tomori, O.; Wacharphaueasadee, S. Preventing the next pandemic: The power of a global viral surveillance network. BMJ 2021, 372, n485. [CrossRef]

87. Sikkema, R.S.; Koopmans, M.P.G. Preparing for emerging zoonotic viruses. In Encyclopedia of Virology, 4th ed.; Bamford, D.H., Zuckerman, M., Eds.; Elsevier: Amsterdam, The Netherlands; Academic Press: Cambridge, MA, USA, 2021; Volume 5, pp. 256-266. [CrossRef]

88. ten Have, H.A.M.J. Sheltering at our common home. J. Bioethical Inq. 2020, 17, 525-529. [CrossRef] 
89. Onwezen, M.C.; Bouwman, E.P.; Reinders, M.J.; Dagevos, H. A systematic review on consumer acceptance of alternative proteins: Pulses, algae, insects, plant-based meat alternatives, and cultured meat. Appetite 2021, 159, 105058. [CrossRef]

90. Lurie, M. Giving Smarter in the Age of COVID-19: A Turning Point for Planetary Health; Milken Institute, Center for Strategic Philanthropy: Santa Monica, CA, USA, 2020. Available online: https://milkeninstitute.org/sites/default/files/reports-pdf/MI_ Environment\%20Report_R6\%20\%282\%29.pdf (accessed on 8 May 2021).

91. Bennett, G.; Young, E.; Butler, I.; Coe, S. The impact of lockdown during the COVID-19 outbreak on dietary habits in various population groups: A scoping review. Front. Nutr. 2021, 8, 626432. [CrossRef] [PubMed]

92. Górnicka, M.; Drywień, M.A.; Zielinska, M.A.; Hamułka, J. Dietary and lifestyle changes during COVID-19 and the subsequent lockdowns among Polish adults: A cross-sectional online survey PLifeCOVID-19 study. Nutrients 2020, 12, 2324. [CrossRef] [PubMed]

93. Ruiz-Roso, M.B.; de Carvalho Padilha, P.; Mantilla-Escalante, D.C.; Ulloa, N.; Brun, P.; Acevedo-Correa, D.; Arantes Ferreira Peres, W.; Martorell, M.; Aires, M.T.; de Oliveira Cardoso, L.; et al. COVID-19 confinement and changes of adolescent's [sic] dietary trends in Italy, Spain, Chile, Colombia and Brazil. Nutrients 2020, 12, 1807. [CrossRef] [PubMed]

94. Pérez-Rodrigo, C.; Citores, M.G.; Hervás Bárbara, G.; Litago, F.R.; Casis Sáenz, L.; Aranceta-Bartrina, J.; Val, V.A.; López-Sobaler, A.M.; Martínez De Victoria, E.; Ortega, R.M.; et al. Cambios en los hábitos alimentarios durante el periodo de confinamiento por la pandemia COVID-19 en España. Rev. Esp. Nutr. Comunitaria 2020, 26, 2. [CrossRef]

95. Rodríguez-Pérez, C.; Molina-Montes, E.; Verardo, V.; Artacho, R.; García-Villanova, B.; Guerra-Hernández, E.J.; Ruíz-López, M.D. Changes in dietary behaviours during the COVID-19 outbreak confinement in the Spanish COVIDiet study. Nutrients 2020, 12, 1730. [CrossRef] [PubMed]

96. FAO. Food Outlook—Biennual Report on Global Food Markets: June 2020; Food Outlook, 1; FAO: Rome, Italy, 2020. [CrossRef]

97. Attwood, S.; Hajat, C. How will the COVID-19 pandemic shape the future of meat consumption? Public Health Nutr. 2020, 23, 3116-3120. [CrossRef] [PubMed]

98. Lee, C.G. Industrial Animal Agriculture in the Pandemic Spotlight. ABA Tort Trial \& Insurance Practice Section Animal Law Committee Newsletter, Winter/Spring 2021. SSRN. 2021. Available online: https:/ / ssrn.com/abstract=3810976 (accessed on 10 May 2021).

99. Schockmel, M.A. The COVID-19 pandemic: An opportunity to go vegan? ResearchGate 2020. [CrossRef]

100. Mintel: Pass the Avocado on Toast: A Quarter of Young Millennials Say COVID-19 Has Made a Vegan Diet More Appealing. Available online: https://www.mintel.com/press-centre/food-and-drink/pass-the-avocado-on-toast-a-quarter-of-youngmillennials-say-COVID-19-has-made-a-vegan-diet-more-appealing (accessed on 18 April 2021).

101. Dhont, K.; Piazza, J.; Hodson, G. The role of meat appetite in willfully disregarding factory farming as a pandemic catalyst risk. Appetite 2021, 164, 105279. [CrossRef]

102. Niemiec, R.; Jones, M.S.; Mertens, A.; Dillard, C. The effectiveness of COVID-related message framing on public beliefs and behaviors related to plant-based diets. Appetite 2021, 16. [CrossRef]

103. Bryant, C.; Sanctorum, H. Alternative proteins, evolving attitudes: Comparing consumer attitudes to plant-based and cultured meat in Belgium in two consecutive years. Appetite 2021, 161, 105161. [CrossRef] [PubMed]

104. Alvseike, O.; Tollersrud, T.; Blagojević, B. Are pandemics associated with intensive livestock production? Vet. Glas. 2021, 75, 33-41. [CrossRef]

105. Scott, A.B.; Singh, M.; Groves, P.; Hernandez-Jover, M.; Barnes, B.; Glass, K.; Moloney, B.; Black, A.; Toribio, J.A. Biosecurity practices on Australian commercial layer and meat chicken farms: Performance and perceptions of farmers. PLoS ONE 2018, 13, e0195582. [CrossRef] [PubMed]

106. Roy, S.C. Corona virus-its origin, replication and remedy for future threat. Sci. Cult. 2020, 86, 138-144. [CrossRef]

107. European Commission. Ban on Antibiotics as Growth Promoters in Animal Feed Enters into Effect. Press Release IP/05/1687 on 22 December 2005. Available online: https:/ / ec.europa.eu/commission/presscorner/detail/en/IP_05_1687 (accessed on 15 May 2021).

108. Wielinga, P.R.; Jensen, V.F.; Aarestrup, F.M.; Schlundt, J. Evidence-based policy for controlling antimicrobial resistance in the food chain in Denmark. Food Control 2014, 40, 185-192. [CrossRef]

109. Aarestrup, F.M.; Jensen, V.F.; Emborg, H.-D.; Jacobsen, E.; Wegener, H.C. Changes in the use of antimicrobials and the effects on productivity of swine farms in Denmark. Am. J. Vet. Res. 2010, 71, 726-733. [CrossRef]

110. Dillon, M.A. The Impact of Restricting Antibiotic Use in Livestock: Using a 'One Health' Approach to Analyze Effects of the Veterinary Feed Directive. Master's Thesis, Harvard University, Cambridge, MA, USA, November 2020. Available online: https:/ / nrs.harvard.edu/URN-3:HUL.INSTREPOS:37365628 (accessed on 20 May 2021).

111. Hosain, Z.; Kabir, L.; Kamal, M. Antimicrobial uses for livestock production in developing countries. Vet. World 2021, 14, $210-221$. [CrossRef]

112. Gilbert, W.; Thomas, L.F.; Coyne, L.; Rushton, J. Review: Mitigating the risks posed by intensification in livestock production: The examples of antimicrobial resistance and zoonoses. Animal 2021, 15, 100123. [CrossRef]

113. de Vries, M.; van Middelaar, C.E.; de Boer, I.J.M. Comparing environmental impacts of beef production systems: A review of life cycle assessments. Livest. Sci. 2015, 178, 279-288. [CrossRef]

114. Muller, A.; Schader, C.; El-Hage Scialabba, N.; Brüggemann, J.; Isensee, A.; Erb, K.-H.; Smith, P.; Klocke, P.; Leiber, F; Stolze, M; et al. Strategies for feeding the world more sustainably with organic agriculture. Nat. Commun. 2017, 8, 1290. [CrossRef] 
115. Treich, N. Cultured meat: Promises and challenges. Environ. Resour. Econ. 2021, 79, 33-61. [CrossRef] [PubMed]

116. Bonnet, C.; Bouamra-Mechemache, Z.; Réquillart, V.; Treich, N. Viewpoint: Regulating meat consumption to improve health, the environment and animal welfare. Food Policy 2020, 97, 101847. [CrossRef]

117. Funke, F.; Mattauch, L.; van den Bijgaart, I.; Godfray, C.; Hepburn, C.J.; Klenert, D.; Springmann, M.; Treich, N. Is meat too cheap? Towards optimal meat taxation. SSRN 2021. [CrossRef]

118. Parker, C.; Carey, R.; Haines, F.; Johnson, H. Can labelling create transformative food system change for human and planetary health? A case study of meat. Int. J. Health Policy Manag. 2020, 1-12. [CrossRef]

119. Tian, M.; He, X.; Feng, Y.; Wang, W.; Chen, H.; Gong, M.; Liu, D.; Clarke, J.; van Eerde, A. Pollution by antibiotics and antimicrobial resistance in livestock and poultry manure in China, and countermeasures. Antibiotics 2021, 10, 539. [CrossRef] [PubMed]

120. Schulze, M.; Spiller, A.; Risius, A. Food retailers as mediating gatekeepers between farmers and consumers in the supply chain of animal welfare meat—studying retailers' motives in marketing pasture-based beef. Food Ethics 2019, 3, 41-52. [CrossRef]

121. Esbjerg, L.; Burt, S.; Pearse, H.; Glanz-Chanos, V. Retailers and technology-driven innovation in the food sector: Caretakers of consumer interests or barriers to innovation? Br. Food J. 2016, 118, 1370-1383. [CrossRef]

122. Abd-Alrazaq, A.; Alhuwail, D.; Househ, M.; Hamdi, M.; Shah, Z. Top concerns of tweeters during the COVID-19 pandemic: Infoveillance study. J. Med. Internet Res. 2020, 22, e19016. [CrossRef] [PubMed]

123. Nezlek, J.B.; Forestell, C.A. Vegetarianism as a social identity. Curr. Opin. Food Sci. 2020, 33, 45-51. [CrossRef]

124. Marrone, G.; Guerriero, C.; Palazzetti, D.; Lido, P.; Marolla, A.; Di Daniele, F.; Noce, A. Diet health benefits in metabolic syndrome. Nutrients 2021, 13, 817. [CrossRef] [PubMed]

125. Alexandratos, N.; Bruinsma, J. World Agriculture towards 2030/2050: The 2012 Revision; ESA Working Paper No. 12-03; Food and Agriculture Organization (FAO): Rome, Italy, 2012. Available online: http:/ / www.fao.org/3/ap106e/ap106e.pdf (accessed on 7 June 2021).

126. Raheem, D.; Carrascosa, C.; Oluwole, O.B.; Nieuwland, M.; Saraiva, A.; Millán, R.; Raposo, A. Traditional consumptiuon of and rearing edible insects in Africa, Asia and Europe. Crit. Rev. Food Sci. Nutr. 2019, 59, 2169-2188. [CrossRef] [PubMed]

127. Dempsey, C.; Bryant, C. Cultured meat: Do Chinese consumers have an appetite? OSF 2020. [CrossRef]

128. Bryant, C.; Szejda, K.; Parekh, N.; Deshpande, V.; Tse, B. A survey of consumer perceptions of plant-based and clean meat in the USA, India, and China. Front. Sustain. Food Syst. 2019, 3, 11. [CrossRef]

129. Gravel, A.; Doyen, A. The use of edible insect proteins in food: Challenges and issues related to their functional properties. Innov. Food Sci. Emerg. Technol. 2020, 59, 102272. [CrossRef]

130. Chriki, S.; Hocquette, J.-F. The myth of cultured meat: A review. Front. Nutr. 2020, 7, 7. [CrossRef]

131. Jairath, G.; Mal, G.; Gopinath, D.; Singh, B. A holistic approach to access the viability of cultured meat: A review. Trends Food Sci. Technol. 2021, 110, 700-710. [CrossRef]

132. Shi, W.; Gao, G.F. Emerging H5N8 avian influenza viruses. Science 2021, 372, 784-786. [CrossRef]

133. Li, F.C.K.; Choi, B.C.K.; Sly, T.; Pak, A.W.P. Finding the real case-fatality rate of H5N1 avian influenza. J. Epidemiol. Community Health 2008, 62, 555-559. [CrossRef] 